\title{
Evaluation of several end-of-pipe measures proposed to control cyanobacteria
}

\author{
Miquel Lürling • Guido Waajen • \\ Lisette N. de Senerpont Domis
}

Received: 9 December 2014/ Accepted: 7 December 2015/Published online: 24 December 2015

(C) The Author(s) 2015. This article is published with open access at Springerlink.com

\begin{abstract}
While reduction in nutrient loading is a prerequisite for mitigation of harmful cyanobacterial blooms in nutrient-enriched waters, in certain surface waters eutrophication control is not always feasible due to practical and economic constraints or might be effective only in the long run. Yet, the urgent need to control cyanobacteria in water for drinking, irrigation, aquaculture, industry and recreation has spurred the development of a plethora of alternative methods that claim to be fast acting. Here, we provide a critical overview of several of these end-of-pipe measures: effective microorganisms $\left(\mathrm{EM}^{\circledR}\right)$, golden algae (Ochromonas), plant/tree extracts, ultrasound and artificial mixing of non-stratifying waters. Most of the end-of the pipe measures claim to provide
\end{abstract}

Guest editors: Petra M. Visser, Bas W. Ibelings, Jutta Fastner \& Myriam Bormans/Cyanobacterial blooms. Ecology, prevention, mitigation and control.

M. Lürling $(\bowtie) \cdot$ G. Waajen · L. N. de Senerpont Domis Aquatic Ecology and Water Quality Management Group, Department of Environmental Sciences, Wageningen University, Droevendaalsesteeg 3a, 6708 PB Wageningen, The Netherlands

e-mail: miquel.lurling@wur.nl

M. Lürling · L. N. de Senerpont Domis

Department of Aquatic Ecology, Netherlands Institute for Ecology, Wageningen, The Netherlands

G. Waajen

Water Authority Brabantse Delta, P.O. Box 5520,

4801 DZ Breda, The Netherlands sustainable control of harmful cyanobacterial blooms, while at best only targeting symptom relief rather than eutrophication relief. Support for "effective" microorganisms, golden algae, plant extracts, ultrasound and artificial mixing of non-stratifying waters to diminish eutrophication problems such that the resulting water quality meets societal and legislation demands is limited, and several proposed underlying mechanisms are doubtful. None of these curative measures seem the desired wide applicable solution to cyanobacterial nuisance; they should not be considered Columbus's egg. A critical evaluation of end-of pipe measures is crucial for water authorities in their choice for mitigating measures.

Keywords Curative measures - Cyanobacteria suppression · Eutrophication control · Lake management $\cdot$ Lake restoration $\cdot$ Mitigation

\section{Introduction}

Excessive nutrient loading is the major cause of water blooms of cyanobacteria (blue-green algae), i.e., elevated densities throughout the water column (Conley et al. 2009; Smith et al. 1999). Water blooms may cause high turbidity and mal odor of the water, while associated nocturnal oxygen deficiency can lead to fish kills (Paerl and Huisman 2008; Smith et al. 1999). Such blooms may have significant detrimental 
environmental impacts by food web changes reducing biodiversity (Paerl 2008; Paerl et al. 2001). Cyanobacterial blooms have caused drinking water shortages (Yang and Liu 2010) and pose a serious health threat because cyanobacteria might produce potent toxins (Codd et al. 2005; Dittmann and Wiegand 2006). This is especially the case when in a stable water column in lakes and ponds floating layers or surface scums develop that might be further concentrated on the leeside shore, resulting in a manifold concentration of the mostly intracellular contained toxins (Chorus et al. 2000).

Because of the paramount role of nutrient loading in the development of cyanobacteria blooms and scums, nutrient input reductions are the most obvious targets in controlling cyanobacteria harmful blooms (Paerl and Otten 2013). The reduction in external nutrient loading is a prerequisite for improvement, but lake recovery can be delayed for decades due to internal phosphorus loading (Søndergaard et al. 1999). Consequently, hazardous cyanobacterial blooms may remain in these waters for many years. In other systems, such as open systems with intense agricultural influence, nutrient input reductions may not always be possible and cyanobacteria blooms will sustain. Such blooms are clashing with modern society's demand for good water quality (Steffensen 2008) and are in conflict with the attainment of a good water quality needed to comply with both the EU Water Framework Directive (WFD, European Union 2000) and the EU Bathing Water Directive (BWD; European Union 2006). Despite water authorities displaying a great need for preventive measures leading to nutrient reduction and thus to the reduction in cyanobacteria blooms in the long term, they also need short-term fast acting, curative treatments to mitigate cyanobacterial nuisance.

Curative methods should rapidly suppress the proliferation of cyanobacteria or destroy a massive bloom bringing immediate improvement of the water quality and should provide, at least in the growing season, access to the water for drinking, irrigation, aquaculture, industry and recreation (Jancula and Maršálek 2011). Several of these curative measures, such as the application of cyanocides and algicides (Jancula et al. 2016), and manipulations of the food web through macrophytes (Bakker and Hilt 2016) and artificial mixers (Visser et al. 2016) have been dealt with elsewhere in this special issue. Nonetheless, many products remain of which quite a number often have been proposed to water authorities as end-all solutions in controlling cyanobacteria, especially following upon the typical heat waves of 2003 and 2006 with numerous cyanobacterial bloom events in northwestern and central Europe. Here, we will critically review the claims and effectiveness of a selection of methods: i.e., "effective" microorganisms, golden algae, plant extracts and ultrasound. The choice for this selection is based on the scientific information available and the strong promotion or media attention the products received in the Netherlands over the last decade, where golden algae got quite some media attention, questions about "effective" microorganisms made it into the National Parliament, while ultrasound, Barley straw and SolarBee ${ }^{\circledR}$ trials were conducted in situ. A critical review of these end-of pipe measures might be helpful to water authorities in making a more balanced decision for effective treatments to control eutrophication and mitigate cyanobacterial nuisance.

\section{Effective microorganisms $\left(\mathbf{E M}^{\circledR}\right)$}

The use of effective microorganisms (EM) has been advocated to be an end-all solution to a wide suite of water quality problems (e.g., URL1-5; Zakaria et al. 2010). A blend of EM can be kneaded into dried mud to form mud balls that can be thrown in water bodies. These "EM-mudballs" are based on a concept that was first developed by Higa (1998), who suggested that-through competitive exclusion-addition of EM- ${ }^{\circledR}$ changes the microbial community toward dominance of beneficial species, while suppressing harmful bacteria. EM cocktails are allegedly said to contain about 80 species of microorganisms, such as photosynthetic bacteria, lactic acid bacteria, actinomycetes, yeasts and fermenting fungi (Higa 1998). However, this could not be confirmed by analysis of EM- ${ }^{\circledR}$ samples that revealed the majority consisted of lactic acid bacteria (Lactobacillus and Lactococcus at $5-10 \times 10^{6} \mathrm{~mL}^{-1}$ ) and yeasts (Saccharomyces and Candida at about $10^{5} \mathrm{~mL}^{-1}$ ), while other microorganisms were present in very low concentrations or not present at all (Van Egeraat 1998). Semiquantitative PCR-DGGE could not confirm the stated richness of EM either (Van Vliet et al. 2006). 
EM claims range from water purification to sustainable end-all solution for water quality and sanitation problems. These claims can be found on various webpages and are based on anecdotal evidence rather than on scientifically confirmation with reproducible and consistent data (Higa and Parr 1994). For example, the statement "Using EM- ${ }^{\circledR}$ Microbial Inoculant on a regular basis will help to keep enough beneficial microbes in the system to keep nutrient levels low enough to prevent the growth of algae" (URL6) is not supported by any scientific study.

There are only limited scientific studies on the use of EM to control nutrients or cyanobacteria in aquatic systems. A recent study showed that the combination of EM and submerged plants, Hydrilla verticillata, had good removal of total nitrogen (TN) and total phosphorus (TP) (Chen et al. 2013). Also humic substance removal by EM was studied, and although the authors report good removal of humic substances by EM (Joo and Foldenyi 2012), the lack of proper controls should be noted. In a $1200-\mathrm{m}^{2}$ pond in Poland fed by purified water from a sewage plant, several water quality variables were measured in a period before and after the addition of EM (Jóźwiakowski et al. 2009). Although the preliminary data of Jóźwiakowski et al. (2009) indicate a decrease in both $\mathrm{TN}$ and TP, the limited sampling regime (twice in winter, once in spring) does not allow for drawing definite conclusions on the effectivity on the application of EM. Application of four mudballs and $2.5 \mathrm{~L}$ liquid material both containing EM to a $24-\mathrm{m}^{2}$ garden pond in Hungary led to elevated SRP levels and lower transparency indicating the inefficacy of the EM in controlling eutrophication (Padisák 2014).

Controlled experiments in the laboratory found no growth inhibition for a laboratory strain of Microcystis aeruginosa and for M. aeruginosa from the field at a recommended dosage of 1 EM-mudball per square meter ( $\approx 0.1-0.3 \mathrm{~g} \mathrm{~L}^{-1}$ ) (Lürling et al. 2009; 2010). Suspensions of EM-mudballs up to $1 \mathrm{~g} \mathrm{~L}^{-1}$ were ineffective in reducing cyanobacterial growth. Cyanobacteria were inhibited only at very high EMmudball concentrations (5-10 $\mathrm{g} \mathrm{L}^{-1}$ ), because of the very high amount of clay and high water turbidity (Lürling et al. 2009; 2010). Also a suspension of "activated effective microorganism" (EM-A) was not effective in reducing cyanobacteria growth and high concentrations of EM-A caused low $\mathrm{pH}$ of the water and nutrient enrichment (Lürling et al. 2009). High dosage of EM-mudballs caused water column oxygen depletion (Lürling et al. 2009, 2010), release of metals $(\mathrm{Al}, \mathrm{Cd}, \mathrm{Cu}, \mathrm{La}$ and $\mathrm{Pb}$ ) and release of phosphate (Lürling et al. 2009). Hence, such "effective microorganisms" formulations are not effective to prevent the growth of algae or in preventing cyanobacterial proliferation and/or terminating blooms. The Dutch authorities prohibited the application of EM-mudballs in Almere-Haven, because they contained heavy metals such as mercury as well as nutrients (Rijkswaterstaat 2007).

Overall, the claim that EM will "keep nutrient levels low enough to prevent the growth of algae" in surface water is not supported by scientific evidence. In contrast, controlled experiments have clearly shown that cyanobacteria cannot be controlled with EM.

\section{Golden algae (Ochromonas)}

In August 2009, a press release based on a publication of a study with Microcystis and the chrysomonad Ochromonas (Van Donk et al. 2009) led to more than a dozen news items in the Dutch media with main emphasis on the green nature of this promising solution, and a comparison with the use of natural enemies such as predatory mites in horticulture pest control was made (source: LexisNexis ${ }^{\circledR}$ Academic). Consequently, several water authorities considered the use of the shiny golden alga Ochromonas in controlling cyanobacteria.

It is already known for decades that chrysomonads (Ochromonas danica, O. minuta and Poterioochromonas malhamensis) can feed on cyanobacteria (Cole and Wynne 1974; Daley et al. 1973). They can ingest food items several times larger in diameter than their own which is around $10 \mu \mathrm{m}$ (Zhang et al. 1996), seemed to modify or degrade microcystins (Ou et al. 2005) and are capable of growing on sole cyanobacterial food (Zhang and Watanabe 2001). Chrysomonads, however, had no significant effect when Microcystis density was high (Zhang et al. 2009a). On the other hand, Microcystis can respond to the threat of being grazed by chrysomonads by building colonies (Burkert et al. 2001; Wang et al. 2010). Formation of large colonies in Microcystis aeruginosa was observed under continuous grazing pressure by Ochromonas that allowed Microcystis population growth (Yang and Kong 2012). Those colonies were protected from Ochromonas grazing, which was further 
corroborated in studies that showed low clearance rates on colonial M. aeruginosa compared to unicells (Yang et al. 2009b, c). Thus, a common bloom-forming organism like Microcystis had simply grown to sizes beyond the ingestion capacity of the chrysomonads. In eutrophic systems, the summer increase in phytoplankton contains a high proportion of inedible species (Sommer et al. 2012). There is no evidence that chrysomonads would be capable of grazing down those grazing-resistant phytoplankton, often comprised of large dinoflagellates and/or cyanobacteria (Sommer et al. 1986).

The chrysomonads themselves are on the menu of several larger metazoan grazers, mesozooplankton (Saunders et al. 1994). They can be toxic to mesozooplankton (Boxhorn et al. 1998; Leeper and Porter 1995; Hiltunen et al. 2012), but it is assumed that at normal field abundances of these organisms toxic effects will be hardly detectable (Boenigk and Stadler 2004). Grazing by chrysomonads on Microcystis can also reduce the toxicity of Microcystis to Daphnia (Zhang et al. 2009b). Therefore, chrysomonads are often controlled by mesozooplankton (Sommer et al. 2012).

While Ochromonas and Poterioochromonas might be widespread and common mixotrophs (Boenigk and Stadler 2004; Van Donk et al. 2009), the incidence and intensity of cyanobacterial blooms have increased over the last decades (O'Neil et al. 2012), strongly suggesting that the chrysomonads fail to control cyanobacteria in the field. Mass culture and depositing chrysomonads in the field are advised against, because of the expected lack of effect and the addition of nutrients to the receiving water.

\section{Plant/tree extracts}

A whole array of plant extracts and chemicals exuded by macrophytes for controlling cyanobacteria is promoted. In a thorough review, it was concluded that "With many findings on new allelochemicals, it will become the most promising method to control algal bloom" (Hu and Hong 2008). Among the most studied is barley straw (extracts) that could reduce growth of unicellular and filamentous green algae (Welch et al. 1990; Gibson et al. 1990) and cyanobacteria such as Microcystis aeruginosa (Newman and Barrett 1993). During straw decomposition under UVsupplemented visible light, hydrogen peroxide was produced that might have caused inhibition of $M$. aeruginusa (Iredale et al. 2012). This could explain the differences in sensitivity between eukaryotic algae and cyanobacteria as cyanobacteria in general are more sensitive to hydrogen peroxide than green algae and diatoms (Drábková et al. 2007). The active compounds, polyphenols (Pillinger et al. 1994; Ridge and Pillinger 1996), have recently been identified as salcolin A and B (Xiao et al. 2014). Salcolin A caused after 1 day an increase in M. aeruginosa intracellular reactive oxygen species (Xiao et al. 2014). The findings have triggered speculations on the use of barley straw for controlling $M$. aeruginosa blooms (Shao et al. 2013) and more specific the use of salcolin in the "future control of cyanobacterial harmful algae blooms" (Xiao et al. 2014). However, a protective role of microcystins against oxidative stress has been suggested too (e.g., Phelan and Downing 2011), which finds further support in an experiment where a microcystin producing $M$. aeruginosa strain was better protected against oxidative stress caused by hydrogen peroxide than its microcystin-free mutant (Zilliges et al. 2011). Hence, increased oxidative stress caused by the decaying barley straw could potentially select for more toxic (microcystin producing) cyanobacteria.

Applying rotting barley straw (50 and $25 \mathrm{~g} \mathrm{~m}^{-3}$ ) to shallow reservoirs inhibited phytoplankton and lowered cyanobacteria dominance (Everall and Lees 1996; 1997). Repeated addition of barley straw $\left(6-28 \mathrm{~g} \mathrm{~m}^{-3}\right)$ to a reservoir lowered phytoplankton and cyanobacteria cell numbers to one half or to one quarter (Barrett et al. 1999). A pond experiment with different barley straw dose (40 and $80 \mathrm{~g} \mathrm{~m}^{-2}$ ) revealed inhibition of $M$. aeruginosa, Anabaena sp. and Aphanizomenon sp., no effect on Nostoc sp. and a stimulation of Oscillatoria sp. (Rajabi et al. 2010), while another pond experiment showed no difference between controls and barley-treated ponds (Ferrier et al. 2005). The phytoplankton abundance in a loch treated with barley bales declined after 10 months compared to an untreated loch and remained low for subsequent 17 months (Harriman et al. 1997). In contrast, in another Scottish loch, barley had no effect on phytoplankton and no evidence for such a delayed effect of straw bale placement was detected as April placement was followed by an August bloom (Kelly and Smith 1996). Likewise, adding barley straw into a rice field did not reduce phytoplankton abundance (Spencer and Lembi 2007) and in an enclosure study 
three different barley concentrations (5, 15 and $60 \mathrm{~g} \mathrm{~m}^{-3}$ ) showed no effects on algae (Boylan and Morris 2003). The latter authors mentioned a case of two ponds where a combination of barley straw and aerators reduced phytoplankton biomass (Boylan and Morris 2003). Positive effects of barley straw on controlling Microcystis and cyanobacteria for some reservoirs in the UK were reported (Purcell et al. 2013), but these find no strong support in the underlying data.

In 1997 and 2000, barley straw was added to an urban pond in Roosendaal (the Netherlands) and in 2000 to a small lake near Waspik. For the latter, mean summer chlorophyll- $a$ concentrations were $156 \mu \mathrm{g} \mathrm{L}^{-1}$ in 1999 prior to barley and $106 \mu \mathrm{g} \mathrm{L}^{-1}$ in 2000 after the barley placement (Water Authority Brabantse Delta). In the urban pond Parkvijver (Roosendaal, the Netherlands), mean summer chlorophyll- $a$ concentrations were $167 \mu \mathrm{g} \mathrm{L}^{-1}$ in 1995 before barley placement, only $23 \mu \mathrm{g} \mathrm{L}^{-1}$ in 1997 during barley presence, $30 \mu \mathrm{g} \mathrm{L}^{-1}$ in $1998,116 \mu \mathrm{g} \mathrm{L}^{-1}$ in 1999 , while after a second barley placement in 2000, mean summer chlorophyll- $a$ concentrations were $306 \mu \mathrm{g} \mathrm{L}^{-1}$. In 1999, phytoplankton was dominated by chlorophytes reaching a maximum phytoplankton cell concentration of $3.4 \times 10^{5}$ cells $\mathrm{mL}^{-1}$ in August, while less than 3 months after the barley placement (beginning March 2000), cyanobacteria already flourished reaching densities of $7.7 \times 10^{5}$ cells $\mathrm{mL}^{-1}$ on May 29,2000 (Fig. 1). End of July, chlorophyll- $a$ and phytoplankton concentrations had dropped, but they increased again after a second application of barley straw in the beginning of August 2000 (Fig. 1).

The mixed results that emerge from field trials have also been obtained in more controlled laboratory assays. In general, M. aeruginosa appears among the most vulnerable organisms (Martin and Ridge 1999; Ferrier et al. 2005). However, not all cyanobacteria seem susceptible to rotting barley straw; no effects were observed in Pseudoanabaena sp. (Brownlee et al. 2003) and growth stimulation has been observed in Anabaena cylindrica, A. flos-aquae, Oscillatoria animalis and $O$. lutea var. contorta (Martin and Ridge 1999; Ferrier et al. 2005). Similarly, barley straw extract had variable effects on dinoflagellates, inhibition of some Heterocapsa species, no effect or stimulation of Gymnodiniales and stimulation of Prorocentrales (Terlizzi et al. 2002). Commercially available barley straw extract had no effect on the ichthyotoxic Prymnesium parvum (Grover et al. 2007). Likewise, testing microbe-lift barley straw concentrated extract $\left(1.5 \times 10^{-4}\right.$ to $\left.15 \mathrm{~mL} \mathrm{~L}^{-1}\right)$ in our laboratory on $M$. aeruginosa (initial chlorophyll$a$ concentration $17 \mu \mathrm{g} \mathrm{L}^{-1}$ ) revealed no growth inhibition (Fig. 2).

Decomposed barley straw extract inhibited $M$. aeruginosa, while fresh extract promoted growth (Ball et al. 2001). Microbial activity appears essential for barley straw to become inhibitory causing a lag period before straw becomes "active." Fine chopping of the straw can shorten this lag phase substantially (Iredale et al. 2012).

As with effects on cyanobacteria, also varying effects on water quality variables have been reported. For example, while in an enclosure study barley straw $\left(1.3 \mathrm{~g} \mathrm{~L}^{-1}\right)$ was effective in suppressing Aphanizomenon flos-aquae, dissolved oxygen levels dropped to near zero (Haggard et al. 2013). In contrast, others found higher oxygen levels in barley-treated ponds (Rajabi et al. 2010) or no effects in an enclosure study (Boylan and Morris 2003). Moreover, the addition of barley straw to mesocosms increased phosphate levels fivefold to tenfold compared to the control (Haggard et al. 2013), whereas in another study, no effects on nutrients were found (Boylan and Morris 2003).

Although widely accepted that barley straw can be an "effective control method" (Purcell et al. 2013), an "effective and environmentally-sound option for the control of cyanobacterial and microalgal blooms" (Iredale et al. 2012) and "very useful for controlling of M. aeruginosa based blooms" (Shao et al. 2013), the lag phase, the different sensitivity of organisms, the contrasting field results and the proposed underlying mechanism of oxidative stress imply that use of rotting barley straw should be met with care.

In addition to barley straw extract, many plantderived chemicals have anti-cyanobacterial activities. These compounds are mostly extracted from plant tissue and then tested on cyanobacteria, mainly $M$. aeruginosa (Table 1). Controlled experiments with extracts of Fructus mume, Salvia miltiorrhiza and Moringa oleifera as well as L-lysine and D-lysine gave no support that these plant extracts and amino acid could be promising candidates for curative application in $M$. aeruginosa bloom control (Lürling and van Oosterhout 2014). From several studies, it is unclear whether the effect is caused by the extract or by the solvent. Often rather high concentrations are needed, 
Fig. 1 Phytoplankton abundance (bars) for cyanobacteria (blue fill), chlorophytes (green fill) and diatoms (brown fill) as well as the course of the chlorophyll- $a$ concentration (solid black line) over the period July 1999-

September 2000. The two vertical dashed lines represent the addition of barley straw. A photograph of the application is added. (Data from: AquaSense 2000; Bijkerk 2000)

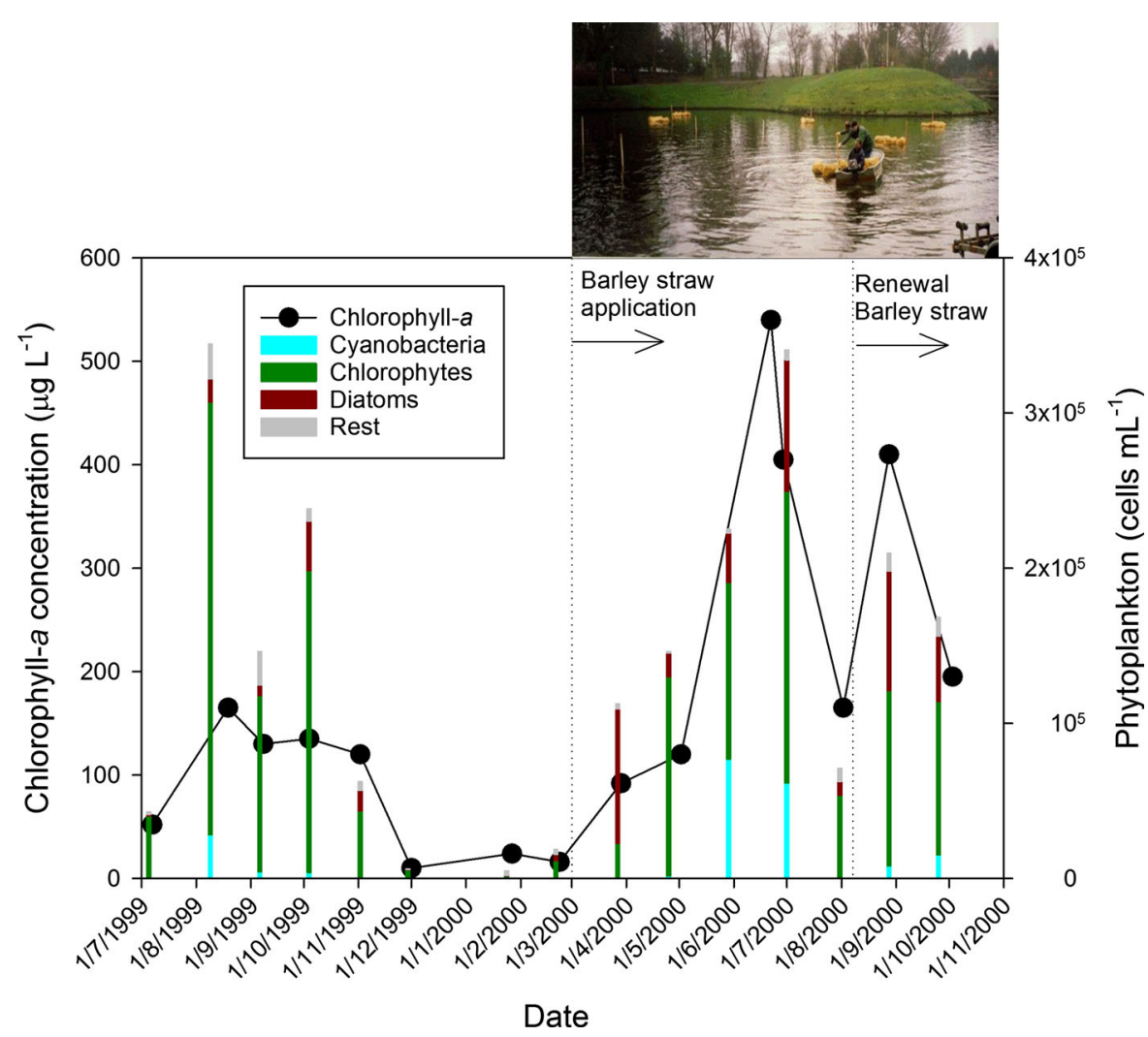

making applications expensive or virtually impossible (Shao et al. 2013). Moreover, concomitant input of nutrients could aggravate eutrophication (Lürling and Beekman 2010; Shao et al. 2013), while high amounts of organic matter in combination with expected warming could lead to higher bloom toxicity (Ekvall et al. 2013).

Plant extracts are often used as synonyms for allelochemicals, despite no proof on their exudation from living plants to the surrounding water exists. The effects of living plants on mitigation of cyanobacterial nuisance are reviewed elsewhere in this issue (Bakker and Hilt 2016). Here we add a few words on allelochemicals, as they might contribute to stabilization of clear water states in shallow lakes (Hilt and Gross 2008). Probably, the life time of active compounds is rather short. For example, in a study with spent medium of Stratiotes aloides in which two strains of $M$. aeruginosa were grown, a delayed lag phase was observed, but as exponential growth rates were equal or slightly higher than the controls (Mulderij et al. 2005), these exposed cyanobacteria apparently caught up rapidly pointing toward rapid decline of the active compounds. Hence, it remains to be seen whether field applications of plant extracts or allelochemicals can produce a window of clear water long enough for submerged and presumably allelopathic active macrophytes to establish. Furthermore, a recent study showed while $M$. aeruginosa was inhibited by macrophyte allelochemicals when growing in pure culture, interacting with a green alga completely reversed inhibition into enhancement (Chang et al. 2012). This led the authors to conclude "allelopathically-active macrophytes might thus support cyanobacteria rather than suppress them in situ" (Chang et al. 2012).

\section{Ultrasound}

Ultrasound is sound of frequencies higher than those that can be detected by the human ear (Mason 2007), i.e., approximately $20 \mathrm{kHz}$ and higher. The frequency range $\sim 20-200 \mathrm{kHz}$ is considered low-frequency ultrasound and used in industry and therapy, while frequencies up to $20 \mathrm{MHz}$ are applied in medical diagnostics (Ahmadi et al. 2012). Ultrasound finds a 


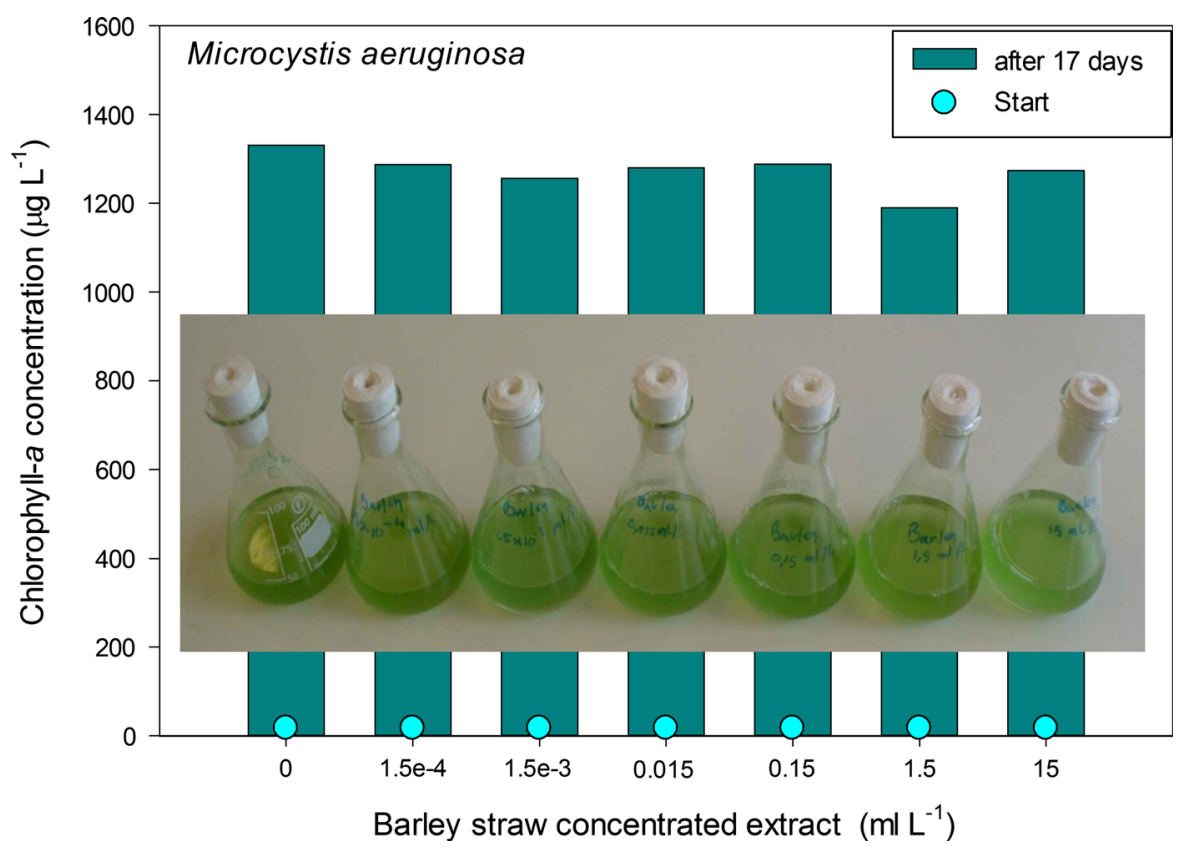

Fig. 2 Chlorophyll- $a$ concentrations of Microcystis aeruginosa after 17-day growth in different concentrations of microbe-lift barley-concentrated extract $\left(0-15 \mathrm{ml} \mathrm{L}^{-1}\right)$. M. aeruginosa was grown in 100-mL Erlenmeyer flasks containing $50 \mathrm{~mL}$ of autoclaved WC medium (Lürling and Beekman 2006) that were placed in a Gallenkamp ORBI-SAFE Netwise Orbital Incubator

large range of applications in medicine, science, industry, including various water treatments (Phull et al. 1997). The alleged potential of ultrasound controlling cyanobacteria in situ is based on several laboratory studies showing clear effects of ultrasound on cyanobacterial growth, the collapse of gas vesicles, cell wall disruption and disturbance of the photosynthetic activity (Wu et al. 2011; Rajasekhar et al. 2012a). The vast majority of these laboratory studies have used high-power devices (e.g., 20-80 W, Hao et al. 2004a; 40-1200 W, Lee et al. 2001) that cause acoustic cavitation: a process in which compression and rarefaction create gas bubbles that may collapse (Neppiras 1980). On collapse of the bubbles, several processes such as pressure gradients, shear forces, formation of radicals and hydrogen peroxide production may disrupt the cells (Joyce et al. 2003). However, such relatively high ultrasound intensities are difficult to apply in lakes and ponds as in larger volumes significantly less power is transmitted, and consequently, the impact on cyanobacteria will be far less (Rajasekhar et al. 2012a). This finds support in at $20^{\circ} \mathrm{C}$, in $60 \mathrm{rpm}$ and in a 18:6-h light:dark rhythm that was programmed to gradually increase light intensity to a maximum of $130 \mu \mathrm{mol}$ quanta $\mathrm{m}^{-2} \mathrm{~s}^{-1}$ and subsequently decreased again to darkness, which resulted in a daily average light intensity of $\sim 57 \mu \mathrm{mol}$ photons $\mathrm{m}^{-2} \mathrm{~s}^{-1}$. A picture of the cultures after 17-day incubation is inserted

some field studies using higher power units-10 units of 2 times $100 \mathrm{~W}(200 \mathrm{kHz})$ in a $365.000-\mathrm{m}^{3}$ reservoir (Lee et al. 2002) and one $630-\mathrm{W}$ unit $(22 \mathrm{kHz})$ in 9000- $\mathrm{m}^{3}$ pond (Ahn et al. 2007). The pond study of Ahn et al. (2007) gave no support for strong cyanobacteria control by ultrasound, because both the control and treated pond were dominated by diatoms and green algae, the treated pond already at start had significantly lower chlorophyll- $a$ concentration than the control, while at the end of the experiment, chlorophyll- $a$ concentrations in both ponds were the same. Lee et al. (2002) reported that chlorophyll- $a$ concentrations were lower in the 2 years of ultrasound treatment, which, however, finds no support in the data as chlorophyll- $a$ concentrations (digitally extracted from figure 4 in Lee et al. 2002), yielded $81( \pm 56) \mu \mathrm{g} \mathrm{L}^{-1}$ before and $74( \pm 42) \mu \mathrm{g} \mathrm{L}^{-1}$ during ultrasound. The intensity in those studies would be around $5.5 \times 10^{-9} \mathrm{~W} \mathrm{~mL}^{-1}$ (in Lee et al. 2002) and $7 \times 10^{-8} \mathrm{~W} \mathrm{~mL}^{-1}$ (in Ahn et al. 2007). Such intensities are much lower than the intensities applied in laboratory studies (mean \pm 1 SD: 


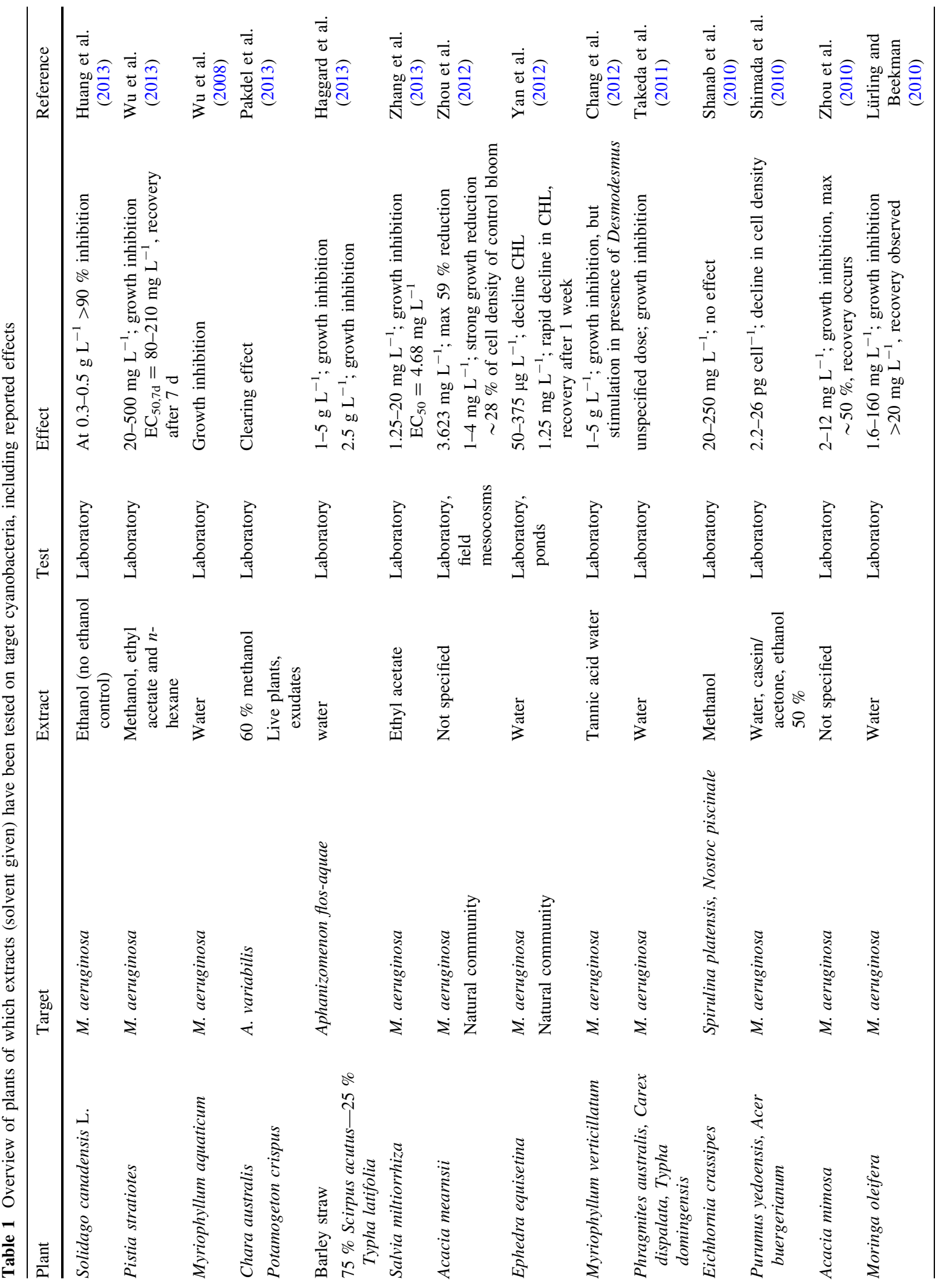




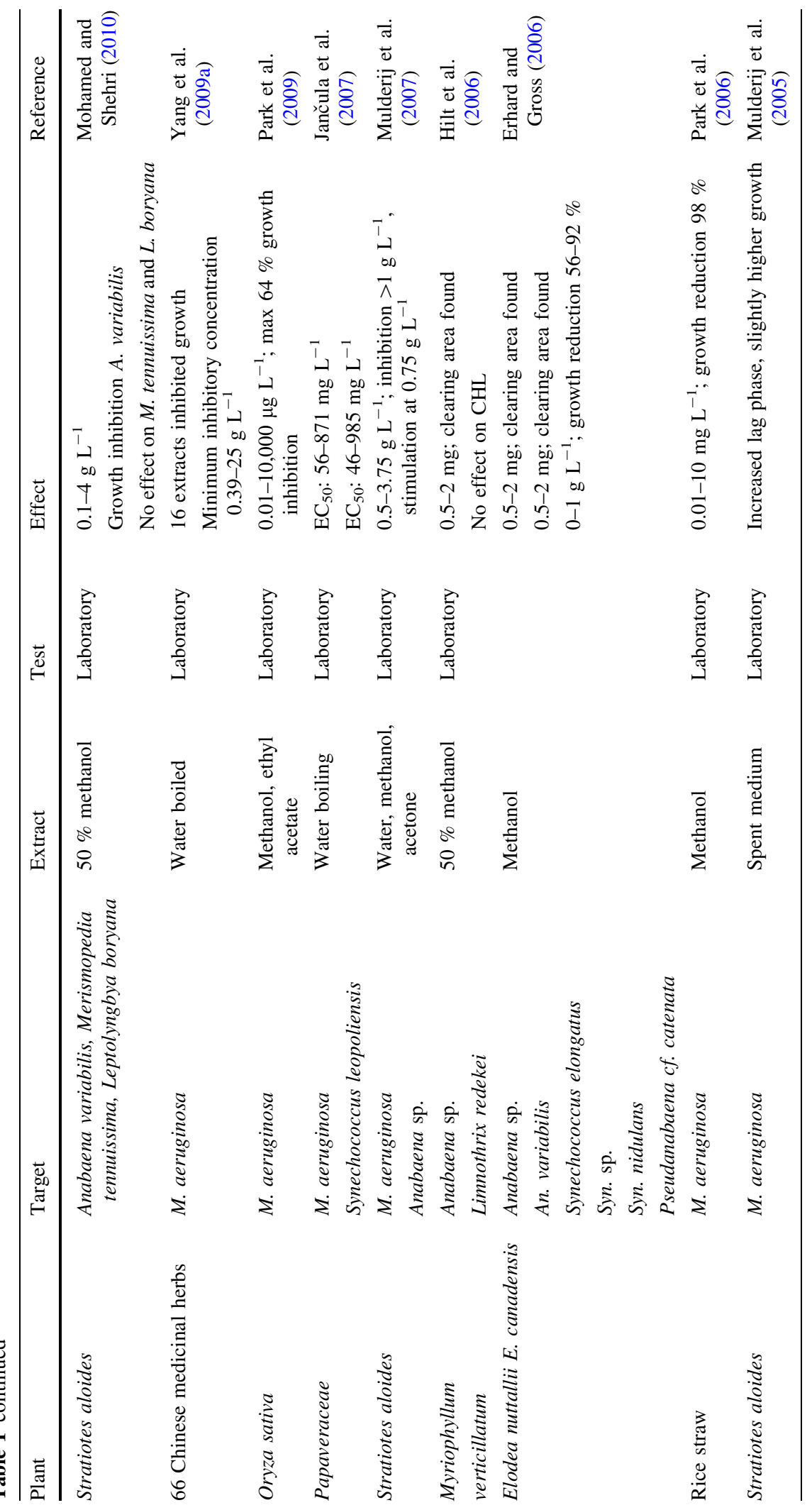


$0.115 \pm 0.084 \mathrm{~W} \mathrm{~mL}^{-1}, \quad n=26,20 / 40 \mathrm{kHz} ; \mathrm{Al}-$ Hamdani et al. 1998; Francko et al. 1990; 1994; Hao et al. 2004a, b; Joyce et al. 2010; Rajasekhar et al. 2012b; Thomas et al. 1989; Zhang et al. 2006; Wu et al. 2012; Rodriguez-Molares et al. 2014).

Intensities of most, if not all, devices that are being sold for clearing lakes, ponds and aquaria are low. Some manufacturers even pointed out that for their commercial available transducers "the occurrence of cavitation can be disregarded" (URL7), or "the method is not cavitation" (URL8). The supposed mode of action "is purely based on killing algae by bringing them in resonance" (URL9). For cyanobacteria, the underlying assumption is that ultrasound will cause resonance and subsequent rupture or collapse of gas vesicles (Rajasekhar et al. 2012a). The resonance frequency $\left(f_{0}\right)$ of gas bubbles can be estimated with the equation (Kotopoulis et al. 2009):

$f_{0}=\frac{1}{2 \pi} \sqrt{\left(\frac{3 \gamma}{R_{0}^{2} \rho}\left(p_{0}+\frac{2 \sigma}{R_{0}}+\frac{2 \chi}{R_{0}}\right)-\left(\frac{2 \sigma+6 \chi}{R_{0}^{3} \rho}\right)\right)}$

in which $\gamma$ is the polytropic exponent of the gas (1.39 for air), $R_{0}$ is the radius of the bubble $(\mu \mathrm{m}), \rho$ is the density of the surrounding liquid $\left(1000 \mathrm{~kg} \mathrm{~m}^{-3}\right), p_{0}$ is the ambient pressure $\left(10^{5} \mathrm{~Pa}\right), \sigma$ is the surface tension of the surrounding medium $\left(\mathrm{Nm}^{-1}\right)$, and $\chi$ is the membrane elasticity $\left(\mathrm{Nm}^{-1}\right)$. The surface tension and membrane elasticity were taken as in Kotopoulis et al.
2009; 0.072 and $0.044 \mathrm{Nm}^{-1}$, respectively. With this equation (Eq. 1), the resonance frequency can be calculated (Fig. 3). As a rule of thumb, the resonance frequency (in $\mathrm{MHz}$ ) can also be approximated by 6.5 / bubble diameter in $\mu \mathrm{m}$ (pers. comm. M. Postema, prof. in acoustics, University of Bergen, Norway).

Equation 1 follows that a sphere with a diameter of $5 \mu \mathrm{m}$ would require $1.3 \mathrm{MHz}$, a $1-\mu \mathrm{m}$ sphere 6.5 MHz, a $0.6-\mu \mathrm{m}$ sphere $11 \mathrm{MHz}$, a $0.1-\mu \mathrm{m}$ sphere $65 \mathrm{MHz}$ and a 60-nm sphere $109 \mathrm{MHz}$ to bring them into resonance. Here, the shape of the gas vesicles is assumed to be spherical, but in reality they have the form of a hollow cylindrical tube (Walsby and Hayes 1989). Gas vesicles in M. aeruginosa have a diameter of 60-70 nm and maximum length of around $600 \mathrm{~nm}$ (Walsby 1994; Dunton and Walsby 2005), which means that it is highly unlikely that low-frequency ultrasound ( $20-200 \mathrm{kHz})$ from such commercial low-power systems will provoke resonance of gas vesicles and subsequent collapse of gas vesicles in the cyanobacteria. However, acoustic cavitation may cause gas vesicle damage (Lee et al. 2001; Rodriguez-Molares et al. 2014), while in the acoustic field near the transducers a high acoustic pressure (power) will kill everything, not only cyanobacteria, but as mentioned before effective control of cyanobacteria in lakes and ponds by such devices is highly questionable.

Also some studies that had used higher-frequency ultrasound $(1700 \mathrm{kHz})$ contain some peculiarities,
Fig. 3 Calculated resonance frequencies (using Eq. 1) of gas bubbles varying in radius $(\mu \mathrm{m})$. Also included are the ranges for cyanobacteria gas vesicles, Microcystis cell, an Anabaena filament and Daphnia

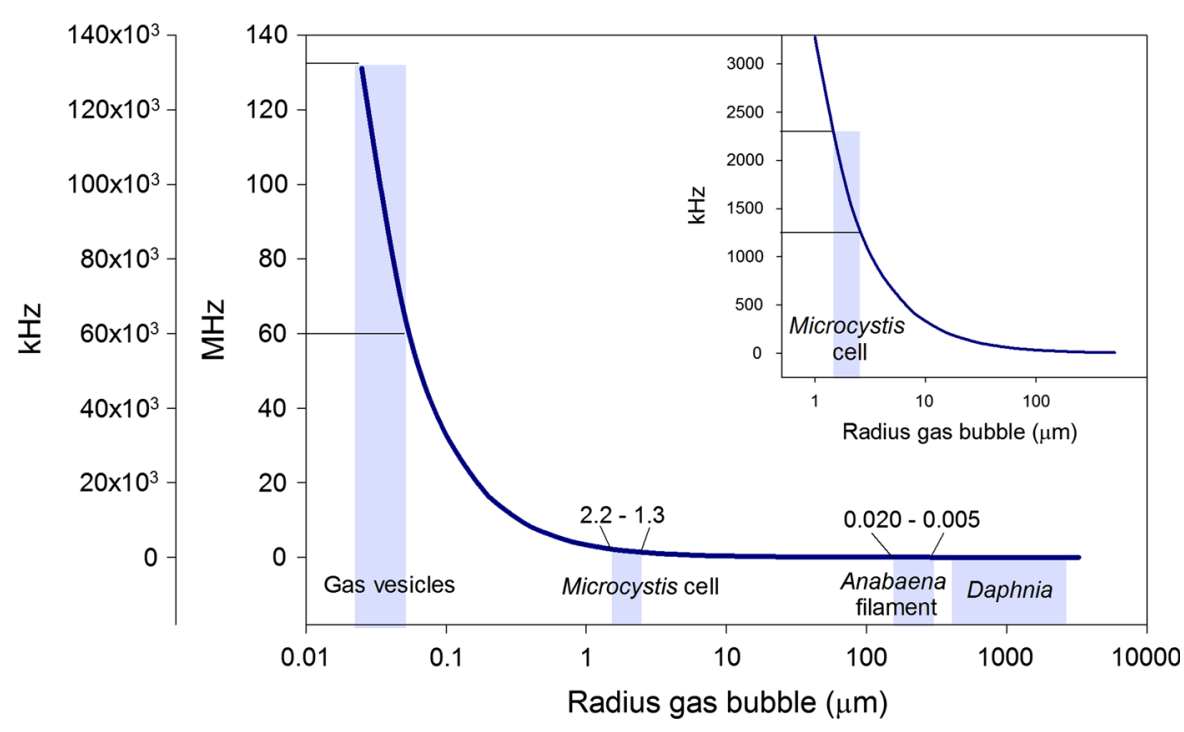




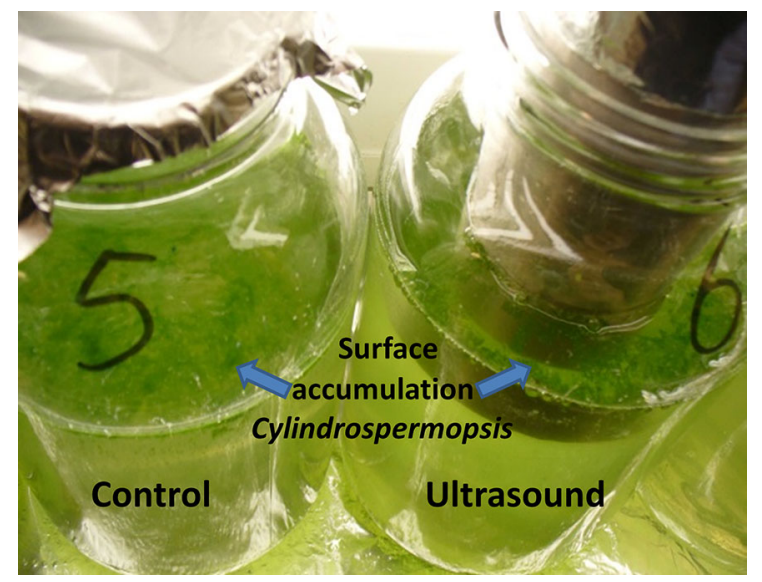

Fig. 4 Jars containing $800 \mathrm{~mL}$ Cylindrospermopsis raciborskii suspension after 10 days of exposure to ultrasound (6) where the surface accumulation is comparable to the control (5)

which make the suggested gas vesicles resonance doubtful; Tang et al. (2004) derived a resonance frequency of " $1.30-2.16 \mathrm{MHz}$ because the $\mathrm{R}$ of the cyanobacteria vacuoles was in the range of $3-5 \mu \mathrm{m}$," while Hao et al. (2004b) mentioned that "the gas vesicles are usually up to $1 \mu \mathrm{m}$ in length." This seems a rather large exaggeration of gas vesicle sizes.

Absence of ultrasound-induced gas vesicle rupture is supported by a controlled experiment with Flexidal AL-10 transducers (Lürling and Tolman 2014a), in which there was not only no wipe out of Cylindrospermopsis raciborskii, but also no effect on buoyancy (Fig. 4). Similarly, Anabaena sp., Microcystis aeruginosa and the green alga Scenedesmus obliquus could not be controlled by these transducers that produced ultrasound at 20,28 and $44 \mathrm{kHz}$ with an acoustic power of 0.7 W (Lürling and Tolman 2014a; Lürling et al. 2014). The experiments unequivocally demonstrated that these devices were not able to clear even small volumes ( $800 \mathrm{~mL}$-intensity of $8.5 \times 10^{-4} \mathrm{~W} \mathrm{~mL}^{-1}$ ) of cyanobacteria or chlorophytes thereby refuting the manufacturers claim that "phytoplankton would be killed within one week" (URL10). However, the zooplankton grazer Daphnia magna was killed within 15-min exposure (Lürling and Tolman 2014a). In a follow-up using Flexidal AL-05 transducers, ultrasound was not able to clear 85-L tanks over a 25-day experimental period (Lürling and Tolman 2014b). Six tanks were inoculated with a mixture of green algae and cyanobacteria and stocked with some zooplankton grazers (Daphnia). While in controls the Daphnia strongly suppressed the phytoplankton creating clear water after 3 weeks, the ultrasound treatments turned into a green phytoplankton-dominated soup (Fig. 5). This was caused by a strong detrimental effect of ultrasound on Daphnia as was demonstrated in additional experiments (Lürling and Tolman 2014b).

The findings that non-target organisms, such as Daphnia, can be killed by ultrasound from the commercial available transducers are in direct conflict with the claim that ultrasound is "environmental friendly" (Rajasekhar et al. 2012a). Actually, such claim and that ultrasound can be considered a "green solution" (Wu et al. 2011) find no support in the literature. None of the studies reviewed in Rajasekhar et al. (2012a) and Wu et al. (2011) included controlled experiments to examine the effect of ultrasound on non-target organisms such as Daphnia. High-power ultrasound is also used for disinfection of ballast water or raw water for drinking water preparation, where it may inactivate motile plankton (Hoyer and Clasen 2002) or kill zooplankton, especially larger

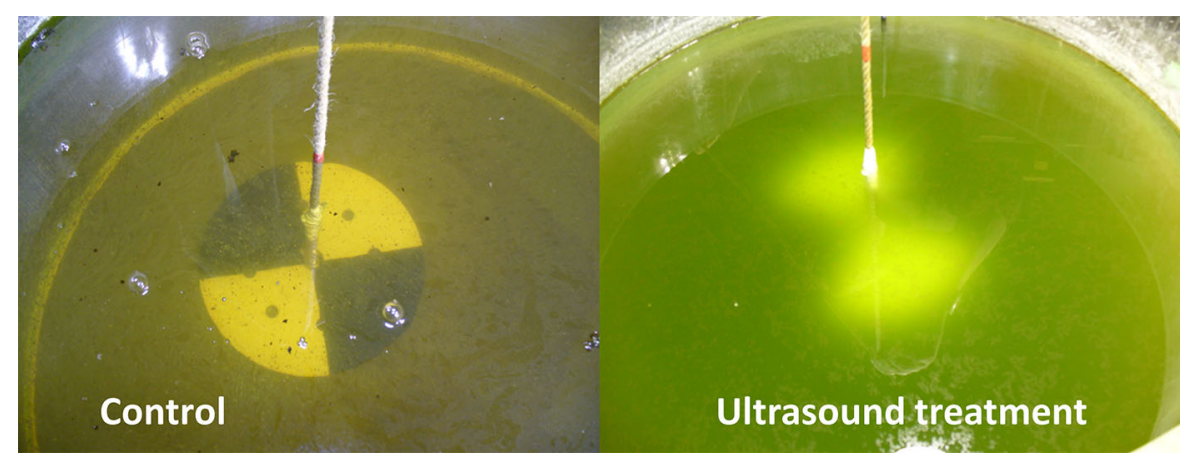

Fig. 5 Pictures after 3-week incubation of a non-exposed (control) and ultrasound-treated 85-L tank (ultrasound treatment) 
cladocerans (Holm et al. 2008). Cavitation might damage fish skin (Frenkel et al. 1999), while detrimental effects of ultrasound on macrophytes have been reported (Carstensen et al. 1990; Wu and $\mathrm{Wu}$ 2006). Hence, high ultrasound intensities might come with danger for non-target organisms in the vicinity of the transducers.

The commercially available ultrasound devices had no water-clearing effect in relatively small volumes of $800 \mathrm{~mL}$ and $85 \mathrm{~L}$ (Lürling and Tolman 2014a,b; Lürling et al. 2014). Likewise, field trials with comparable devices that have been conducted in the Netherlands in 2007, yielded no evidence of an effect of ultrasound on cyanobacteria or phytoplankton (Govaert et al. 2007; Kardinaal et al. 2008). The study of Govaert et al. (2007) was conducted in two identical ponds of which one was treated with ultrasound produced by a Flexidal AL-50 transducer, while the other one served as control. During the four months of operation, chlorophyll- $a$ concentrations in the control were around $64( \pm 13) \mu \mathrm{g} \mathrm{L}^{-1}$ and in the ultrasound treatment around $69( \pm 26) \mu \mathrm{g} \mathrm{L}^{-1}$ (data digitally extracted from Fig. 2 in Govaert et al. 2007). Moreover, no difference in phytoplankton composition was found (Govaert et al. 2007). Kardinaal et al. (2008) described two other field trials in the Netherlands, one in the southwest of the Netherlands in a harbor area near Tholen and the other one in a bay of recreational area De Gouden Ham near the river Maas. Surface scums and high Microcystis densities were observed on both sites despite the ultrasound treatment, and the authors concluded that ultrasound was not effective in reducing cyanobacteria (Kardinaal et al. 2008).

In analogy to what has been reported for bacteria (Joyce et al. 2003; Mason 2007), the effects of ultrasound on cyanobacteria can be grouped as:

- High-intensity (power) ultrasound in small volumes kills cyanobacteria. The devices are predominantly those that are meant for cleaning and sterilization.

- High-intensity (power) ultrasound in large volumes has no lethal effect on cyanobacteria. Filament breakage and colony declumping may occur.

- Low-intensity (power) ultrasound in small volumes does not kill cyanobacteria, but causes filament breakage and some growth reduction.
- Low-intensity ultrasound in large volumes has no effect on cyanobacteria.

\section{The use of artificial mixing devices in non- stratifying waters}

Whereas the use of artificial mixers in stratifying water has been dealt extensively elsewhere in this issue (Visser et al. 2016), we would like to devote a few words to the use of artificial mixers in non-stratifying waters. In a review on the application of aeration in American reservoirs, Pastorok et al. (1980) show that in only $50 \%$ of the cases, artificial mixing was successful. An average depth $>40 \mathrm{~m}$ seems to be necessary to create the light conditions that bring the total phytoplankton biomass down (Klapper 1991). In non-stratifying, mixed systems, the added advantage of being buoyant is limited to non-existent. In these shallow systems, mixing can be even counterproductive, by disrupting the sediment surface and enhancing phosphorus release (Blottiere et al. 2014). Indeed, Barbiero et al. showed that artificial mixing in a small, shallow impoundment close to New York (USA) not only did not result in the desired reduction in cyanobacterial dominance, but also led to an increased flux of phosphorus from the sediment, potentially even fueling more biomass buildup (Barbiero et al. 1996a, b). Also in shallow lake Sheldon $\left(z_{\max }=3.0 \mathrm{~m}\right)$, artificial mixing could not mitigate cyanobacterial blooms (Oberholster et al. 2006). Although artificial mixers such as the Solarbee ${ }^{\circledR}$ have been claimed to mitigate water quality problems in shallower waters by taking away the competitive advantage that buoyant cyanobacteria have over other phytoplankton species that cannot control their buoyancy, the failure to reduce nuisance caused by phytoplankton in shallow systems tells another story (Barkoh et al. 2011; Bocchichio 2012; Hudnell et al. 2010). In July 2013, a Solarbee ${ }^{\circledR}$ was installed in the shallowaverage $2 \mathrm{~m}$ depth-Krabbeplas (the Netherlands) to control cyanobacteria nuisance. However, the already issued swimming ban lasted until beginning September 2013 as cyanobacteria remained flourishing in the lake. For instance, a water sample from August 28, 2013, measured with a PHYTO-PAM revealed $133 \mu \mathrm{g} \mathrm{L}^{-1}$ cyanobacterial chlorophyll- $a$. A warning for cyanobacteria in May 2014 was followed by 

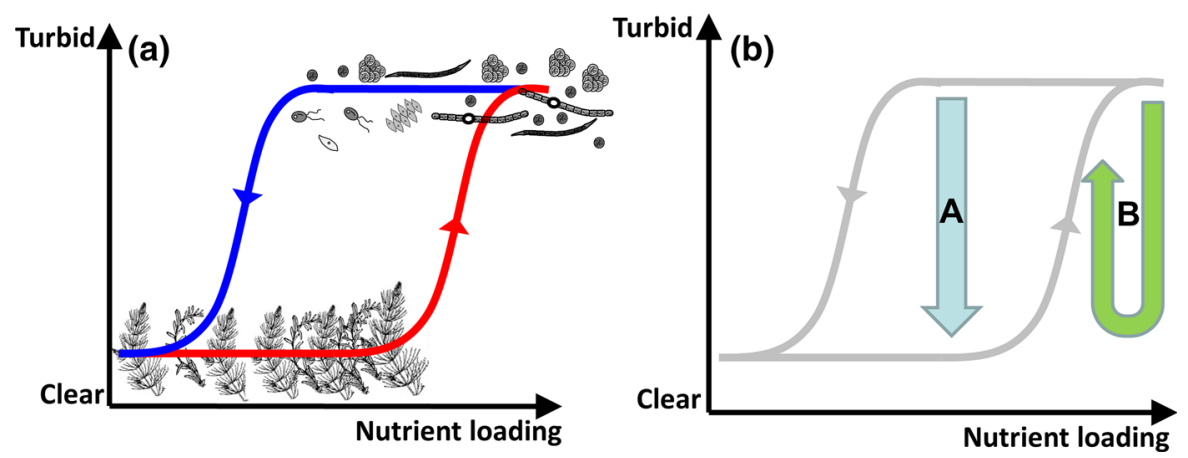

Fig. 6 a Hysteresis in a typical shallow lake where increased nutrient loading leads to a phytoplankton-dominated state that can be brought back to a clear water state with submerged macrophytes by strong reduction in nutrient loading. The critical point of return is at lower loading than the transition to a turbid state ( $c f$. Scheffer et al. 1993). b Shock measures strongly

several warnings and negative bathing advices from June 30, 2014, until September 2014. Hence, the Solarbee ${ }^{\circledR}$ was ineffective in controlling cyanobacteria nuisance in this lake.

In conclusion, we advise against artificial mixing of shallower waters, as sediment release of phosphorus may fuel cyanobacterial blooms rather than mitigate nuisance by cyanobacteria.

\section{Conclusions and recommendations}

Tackling nutrient inputs and internal loading is generally considered a prerequisite for water quality improvement and long-term reduction in cyanobacteria blooms (Cooke et al. 2005; Hilt et al. 2006), but the required preventive measures are not always feasible (Jančula and Maršálek 2011) or may be insufficient to bring the water body in the desired state, which is often a clear water. In particular, in shallow lakes, a typical hysteresis can be observed (Scheffer et al. 1993) where increased nutrient loading first passes by rather unnoticed, stimulating submerged macrophytes, but once crossed a critical loading, the water body shifts into a phytoplankton-dominated state (Fig. 6). This is often a cyanobacteria-dominated state (Scheffer et al. 1997). Reducing the nutrient loading will express little effect on water clarity, unless reduction is very strong traversing a critical loading at much lower values than the one that caused a turbid state, where after the system returns to a clear water state (Fig. 6a). Between

reducing turbidity like end-of-pipe cyanobactericides will be able to bring a system in a clear water state when applied to a water that is below the critical nutrient loading for turbidity (arrow A). However, when applied above the critical loading, the effects will be of short duration and the system will return to a turbid state (arrow B)

those transition boundaries, the water body can have two alternative stable states, a turbid phytoplanktondominated state and a clear water state with submerged macrophytes (Scheffer et al. 1993). Here endof pipe solutions might be of use when nutrient reduction alone has little impact on water clarity (Fig. 6b, arrow A) and a disturbance with a strong water-clearing agent can bring the water back to a stable clear state (Scheffer et al. 1993).

Hence, increased water transparency is one of the desired effects after fast reduction in the cyanobacteria biomass, but the curative products should also improve the water quality long enough to allow submerged macrophytes to establish. To determine whether such a shock therapy might be feasible, a decent system analysis on nutrient loadings is crucial, because interceptions above the critical loading for the transition from clear to turbid (Fig. 6b, arrow B) will only be short-lived and the system will return to its turbid, cyanobacteria-dominated state.

To our opinion, the road to more evidence-based mitigation of cyanobacterial blooms should always start with a system analysis of the specific water system. This implies a thorough investigation of its water and nutrient flows, the biological makeup of the system and the societal environment related to the functions of the specific water. There is broad consensus that nutrient enrichment leads to harmful cyanobacterial blooms (e.g., Paerl et al. 2011) and thus determining the nutrient inputs is a first logical step (Cooke et al. 2005). The nutrient flows separate in 
external load, water and non-water-related and internal load. In deep lakes, acceptable loadings can be derived from empirical relationships (e.g., Vollenweider 1976). The overall nutrient loading for shallow lakes can be evaluated by using the model PCLake (Janse et al. 2008) that will indicate the critical nutrient loads for clear to turbid water and vice versa for the specific water bodies. In relation to the biological makeup, it is crucial to determine whether a water body is packed or not with lake-bottom resuspending fish (carps, breams). If those fish are abundant in densities of hundreds of $\mathrm{kg}$ per hectare, the water will remain in a turbid state by resuspending sediments and preventing submerged macrophyte establishment (e.g., Cline et al. 1994; Roozen et al. 2007). In such cases, fish removal-maybe in combination with macrophyte introduction-should be considered an essential structural measure for rehabilitation. Besides efficiency and applicability, lake managers also need to consider safety, costs and societal support of proposed measures. Consequently, the system analysis will lead to tailor-made solutions and most probably a set of measures rather than one single measure, but also leaving doing nothing as an option (Mackay et al. 2014).

The problem of cyanobacteria blooms and nuisance might be evident and may press water authorities to undertake immediate actions from obvious warnings to even trial and error activities with all kind of "miracle" techniques and products. In that context, numerous products have been proposed to Dutch water authorities as end-all solutions in controlling cyanobacteria. In this review, we have critically evaluated the claims and effectiveness of "effective" microorganisms, golden algae, plant extracts, ultrasound and artificial mixers in non-stratifying lakes. These were selected because of strong promotion or media attention the products/techniques received in the Netherlands over the last decade and of which information is available. There are many more or less comparable products/techniques that are tried by water authorities (e.g., "Dango-balls" URL11, "vortex-system" URL12, "oxatur" URL13, "oil screens" URL14) that have been left out of the evaluation, but of which efficacy is likewise controversial. In general, proposed underlying mechanisms are doubtful. The "effective" microorganisms do not outcompete cyanobacteria, and there is no reason to expect they will improve water quality through diminished cyanobacteria/phytoplankton abundance. Golden algae cannot consume large cyanobacteria, and despite their omnipresence, they apparently fail to control blooms, but even if they did the resulting golden algae bloom would still keep water turbid. Plant extracts are needed in high quantities, might have short-lived effects, might have rather long lag phase and could come with negative side effects such as exacerbated eutrophication, lower oxygen levels or release of cyanotoxins, bringing too much uncertainties to warrant application. Commercially available ultrasound transducers emit frequencies that cannot collapse gas vesicles, and in contrast to the manufacturer's claim, they do not clear the water, but are harmful to other aquatic organisms, at least to Daphnia. The "positive" laboratory studies have all used high-power devices that are designed for cleaning and sterilization through disruption of cells, bacteria, spores or tissue. These devices cannot be used in situ, and even if they would, the much larger volumes would mean a strongly reduced power transmission and thus diminished impact on cyanobacteria. Hence, there is no music in fighting cyanobacteria with ultrasound. Finally, mixing can have positive effects in deeper, stratifying waters (see Visser et al. 2016), but mixing of shallower waters should be avoided as sediment release of phosphorus may fuel cyanobacterial blooms rather than mitigate nuisance by cyanobacteria. Therefore, none of the above seem the wide applicable solution to cyanobacterial nuisance; they should not be considered Columbus's egg.

Nonetheless, in addition to eutrophic lakes and ponds also in oligotrophic and mesotrophic lakes and ponds, cyanobacteria might still be an important component of the plankton community (Lepistö et al. 2005; Carey et al. 2012). Even very low concentrations of cyanobacteria can become positively buoyant, accumulate at the water surface and be further concentrated on leeside shores. In such systems, reduction in nutrient loading is not the measure of first choice, while mechanical removal, sedimentation or killing of the accumulated material seem more feasible. The latter could be achieved with selected plant extracts (Table 1) that comes with abovementioned drawbacks or hydrogen peroxide (Matthijs et al. 2012; Jančula et al. 2016). Whether these will also be applicable when cyanobacteria scums have accumulated in harbors or in the vicinity 
of houses giving strong nuisance mainly through foul odors remains to be seen. Then probably skimming of cyanobacteria off the surface or sinking the intact cells with a coagulant and ballast (e.g., Li and Pan 2013; Lürling and Van Oosterhout 2013) might offer an alternative. There is a wealth of information on the latter technique, where natural soils and clays are modified with flocculants to effectively remove cyanobacteria from the water column (Noyma et al. 2015; Pan et al. 2006a, b, 2011a, b; Zou et al. 2006). An in situ experiment in Lake Taihu applying 25-31 $\mathrm{mg} \mathrm{L}^{-1}$ (40-50 $\mathrm{g} \mathrm{m}^{-2}$ ) effectively cleared an isolated bay of cyanobacteria (Pan et al. 2011a). Inasmuch as in this technique entrapped cyanobacteria in flocks remain intact (Chow et al. 1999; Drikas et al. 2001), no release of toxins and nutrients during treatment occurs. Hence, the stripping of the water column from cyanobacteria might provide a promising alternative to the use of algaecides, such as copper sulfate or hydrogen peroxide, that may come with shortcomings such as toxins and nutrients release (Merel et al. 2013). In stratifying waters, cyanobacteria removal with flocculants and modified clay has yielded promising results too (Lürling and Van Oosterhout 2013; Waajen et al. 2015). Nonetheless, more research on prevention of resuspension or liberation of viable cells from flocks in shallow waters is needed, where inclusion of calcium peroxide pellets (Noyma et al. 2015) or toxin-degrading bacteria ( $\mathrm{Li}$ and Pan 2015) may further improve performance.

Overall, water managers display a great need for effective treatments to control eutrophication and mitigate cyanobacterial nuisance. In order to solve the problems and to select the most promising set of measures, identification of the cause(s) is crucial. Based on the outcome of the essential system analysis, water managers may choose efficient, easy, safe and cheap measures from the tool box that ideally contains numerous preventive and curative measures. However, this critical review clearly showed that there is no strong support for several end-of pipe measures, such as "effective" microorganisms, golden algae, plant extracts, ultrasound and artificial mixers in nonstratifying systems to diminish eutrophication problems such that the resulting water quality meets societal and legislation demands. In that view, rapid interventions through flocking and sinking cyanobacteria with a coagulant and ballast seem more promising and further research should be devoted to these encouraging techniques.

Acknowledgments Jasper Schilling is thanked for his help with the barley-concentrated extract experiment. This is NIOO publication 6000 .

\section{Compliance with ethical standards}

Conflict of interest The authors declare no conflict of interest.

Open Access This article is distributed under the terms of the Creative Commons Attribution 4.0 International License (http:// creativecommons.org/licenses/by/4.0/), which permits unrestricted use, distribution, and reproduction in any medium, provided you give appropriate credit to the original author(s) and the source, provide a link to the Creative Commons license, and indicate if changes were made.

\section{References}

Ahmadi F, McLoughlin IV, Chauhan S, ter-Haar G (2012) Bioeffects and safety of low-intensity, low-frequency ultrasonic exposure. Prog Biophys Mol Biol 108:119-138

Ahn C-Y, Joung S-H, Choi A, Kim H-S, Jang K-Y, Oh H-M (2007) Selective control of cyanobacteria in eutrophic pond by a combined device of ultrasonication and water pumps. Environ Technol 28:371-379

Al-Hamdani S, Burnett C, Durrant G (1998) Effect of low-dose ultrasonic treatment on Spirulina maxima. Aquacult Eng 19:17-28

AquaSense (2000) Fytoplankton gerstestro. Bemonsteringsjaar 2000. Rapport 1847, Amsterdam, The Netherlands (In Dutch)

Bakker L, Hilt S (2016) Impact of water level fluctuations on cyanobacterial blooms: options for management. Aquat Ecol (this issue)

Ball AS, Williams M, Vincent D, Robinson J (2001) Algal growth control by a barley straw extract. Bioresour Technol 77:177-181

Barbiero RP, Ashby SL, Kennedy RH (1996a) The effects of artificial circulation on a small Northeastern impoundment. J Am Water Res Assoc (JAWRA) 32:575-584

Barbiero RP, Speziale BJ, Ashby SL (1996b) Phytoplankton community succession in a lake subjected to artificial circulation. Hydrobiologia 331:109-120

Barkoh A, Begley DC, Smith DG, Kurten GL, Fries LL, Schlechte JW (2011) Can solar powered circulation control Prymnesium parvum blooms and toxicity in fish hatchery ponds? Harmful Algae 10:173-180

Barrett PRF, Littlejohn JW, Curnow J (1999) Long-term algal control in a reservoir using barley straw. Hydrobiologia 415:309-313

Bijkerk R (2000) Soortensamenstelling en abundantie van fytoplankton in een vijver aan de Parklaan te Roosendaal, meetjaar 1999, datarapport. Rapport 2000-25, Koeman en Bijkerk bv, Haren, The Netherlands, (in Dutch) 
Blottiere L, Rossi M, Madricardo F, Hulot FD (2014) Modeling the role of wind and warming on Microcystis aeruginosa blooms in shallow lakes with different trophic status. Theor Ecol 7:35-52

Bocchichio ME (2012) 2012 Blue Lake Water Quality Report. http://www.bluelakeimprovement.org/wp-content/uploads/ 2012/12/2012-blue_lake_water_quality_report_01.pdf

Boenigk J, Stadler P (2004) Potential toxicity of chrysophytes affiliated with Poterioochromonas and related 'Spumellalike' flagellates. J Plankton Res 26:1507-1514

Boxhorn JE, Holen DA, Boraas ME (1998) Toxicity of the Chrysophyte flagellate Poterioochromonas malhamensis to the rotifer Brachionus angularis. Hydrobiologia 387(388):283-287

Boylan JD, Morris JE (2003) Limited effects of barley straw on algae and zooplankton in a midwestern pond. Lake Reserv Manag 19:265-271

Brownlee EF, Sellner SG, Sellner KG (2003) Effects of barley straw (Hordeum vulgare) on freshwater and brackish phytoplankton and cyanobacteria. J Appl Phycol 15:525-531

Burkert U, Hyenstrand P, Drakare S, Blomqvist P (2001) Effects of the mixotrophic flagellate Ochromonas sp. on colony formation in Microcystis aeruginosa. Aquat Ecol 35:9-17

Carey CC, Ewing HA, Cottingham KL, Weathers KC, Thomas RQ, Haney JF (2012) Occurrence and toxicity of the cyanobacterium Gloeotrichia echinulata in low-nutrient lakes in the northeastern United States. Aquat Ecol 46:395-409

Carstensen EL, Child SZ, Crane C, Miller MW, Parker KJ (1990) Lysis of cells in Elodea leaves by pulsed and continuous wave ultrasound. Ultrasound Med Biol 6:167-173

Chang X, Eigemann F, Hilt S (2012) Do macrophytes support harmful cyanobacteria? Interactions with a green alga reverse the inhibiting effects of macrophyte allelochemicals on Microcystis aeruginosa. Harmful Algae 19:76-84

Chen DQ, He H, Chen YQ (2013) Purification of nitrogen and phosphorus in lightly polluted landscape river by effective microorganisms combined with submerged plants. Appl Mech Mater 316-317:430-434

Chorus I, Falconer IR, Salas HJ, Bartram J (2000) Health risks caused by freshwater cyanobacteria in recreational waters. J Toxicol Environ Health Part B 3:323-347

Chow CW, Drikas M, House J, Burch MD, Velzeboer R (1999) The impact of conventional water treatment processes on cells of the cyanobacterium Microcystis aeruginosa. Water Res 33:3253-3262

Cline JM, East TL, Threlkeld ST (1994) Fish interactions with the sediment-water interface. Hydrobiologia 275(276): 301-311

Codd GA, Lindsay J, Young FM, Morrison LF, Metcalf JS (2005) Harmful Cyanobacteria: from mass mortalities to management measures. In: Huisman J, Matthijs HCP, Visser P (eds) Harmful cyanobacteria. Springer, Dortrecht, pp 1-24

Cole GT, Wynne MJ (1974) Endocytosis of Microcystis aeruginosa by Ochromonas danica. J Phycol 10:397-410

Conley DJ, Paerl HW, Howarth RW, Boesch DF, Seitzinger SP, Havens KE, Lancelot C, Likens GE (2009) Controlling eutrophication: nitrogen and phosphorus. Science 323: 1014-1015
Cooke GD, Welch EB, Peterson SA, Nicholas SA (2005) Restoration and management of lakes and reservoirs. CRC Press, Boca Raton

Daley RJ, Morris GP, Brown SR (1973) Phagotrophic ingestion of a blue-green alga by Ochromonas. J Protozool 20:58-61

Dittmann E, Wiegand C (2006) Cyanobacterial toxins-occurrence, biosynthesis and impact on human affairs. Mol Nutr Food Res 50:7-17

Drábková M, Admiraal W, Maršálek B (2007) Combined exposure to hydrogen peroxide and light: selective effects on cyanobacteria, green algae, and diatoms. Environ Sci Technol 41:309-314

Drikas M, Chow CWK, House J, Burch MD (2001) Using coagulation, flocculation and settling to remove toxic cyanobacteria. J Am Water Works Assoc 93:100-111

Dunton PG, Walsby AE (2005) The diameter and critical collapse pressure of gas vesicles in Microcystis are correlated with GvpCs of different length. FEMS Microbiol Lett 247:37-43

Ekvall MK, De La Calle MJ, Faassen EJ, Gustafsson S, Lürling M, Hansson L-A (2013) Synergistic and species-specific effects of climate change and water colour on cyanobacterial toxicity and bloom formation. Freshw Biol 58:2414-2422

Erhard D, Gross EM (2006) Allelopathic activity of Elodea canadensis and Elodea nuttallii against epiphytes and phytoplankton. Aquat Bot 85:203-211

European Union (2000) Directive 2000/60/EG of the European Parliament and of the Council establishing a framework for the Community action in the field of water policy of 23 October, PB L 327 of 22 December 2000

European Union (2006) Directive 2006/7/EC of the European Parliament and of the Council of 15 February 2006 concerning the management of bathing water quality and repealing Directive 76/160/EEC. Off J EU 2006, L64, 37-51, 4 March 2006

Everall N, Lees D (1996) The use of barley straw to control general and blue-green algal growth in a Derbyshire reservoir. Water Res 30:269-276

Everall N, Lees D (1997) The identification and significance of chemicals released from decomposing barley straw during reservoir algal control. Water Res 31:614-620

Ferrier MD, Butler BR, Terlizzi DE, Lacouture R (2005) The effects of barley straw (Hordeum vulgare) on the growth of freshwater algae. Bioresour Technol 96:1788-1795

Francko DA, Taylor SR, Thomas BJ, Mclntosh D (1990) Effect of low-dose ultrasonic treatment on physiological variables in Anabaena flos-aquae and Selenastrum capricornutum. Biotechnol Lett 12:219-224

Francko DA, Al-Hamdani S, Joo G-J (1994) Enhancement of nitrogen fixation in Anabaena flos-aquae (Cyanobacteria) via low-dose ultrasonic treatment. J Appl Phycol $6: 455-458$

Frenkel V, Kimmel E, Iger Y (1999) Ultrasound-induced cavitation damage to external epithelia of fish skin. Ultrasound Med Biol 25:1295-1303

Gibson MT, Welch IM, Barrett PRF, Ridge I (1990) Barley straw as an inhibitor of algal growth II: laboratory studies. J Appl Phycol 2:241-248 
Govaert E, Vanderstukken M, Muylaert K (2007) Evaluatie van effecten van ultrasone straling op het ecosysteem. KULeuven Kortrijk (In Dutch)

Grover JP, Baker JW, Urena-Boeck F, Brooks BW, Errera RM, Roelke DL, Kiesling RL (2007) Laboratory tests of ammonium and barley straw extract as agents to suppress abundance of the harmful alga Prymnesium parvum and its toxicity to fish. Water Res 41:2503-2512

Haggard KG, Geiger NS, Hayes PM, Milligan AJ (2013) Suppression of cyanobacterial growth of Aphanizomenon flosaquae by vascular plant decomposition products in Upper Klamath Lake, Oregon. Lake Reserv Manag 29:13-22

Hao H, Wu M, Chen Y, Tang J, Wu Q (2004a) Cavitation mechanism in cyanobacterial growth inhibition by ultrasonic irradiation. Colloid Surf B 33:151-156

Hao H, Wu M, Chen Y, Tang J, Wu Q (2004b) Cyanobacterial bloom control by ultrasonic irradiation at $20 \mathrm{kHz}$ and 1.7 MHz. J Environ Sci Heal A 39:1435-1446

Harriman R, Adamson EA, Shelton RGJ, Moffett G (1997) An assessment of the effectiveness of straw as an algal inhibitor in an Upland Scottish Loch. Biocontrol Sci Technol 7:287-296

Higa T (1998) Effective Micro-organisms. For Sustainable Agriculture and Healthy Environment, Jan van Arkel, Utrecht (in Dutch)

Higa T, Parr JF (1994) Beneficial microorganisms for a sustainable agriculture and environment. International Nature Farming Research Center, Atami

Hilt S, Gross EM (2008) Can allelopathically active submerged macrophytes stabilise clear-water states in shallow lakes? Basic Applied Ecol 9:422-432

Hilt S, Ghobrial MGN, Gross EM (2006) In situ allelopathic potential of Myriophyllum verticillatum (Haloragaceae) against selected phytoplankton species. J Phycol 42:11891198

Hiltunen T, Barreiro A, Hairston NG Jr (2012) Mixotrophy and the toxicity of Ochromonas in pelagic food webs. Freshwater Biol 57:2262-2271

Holm ER, Stamper DM, Brizzolara RA, Barnes L, Deamer N, Burkholder JM (2008) Sonication of bacteria, phytoplankton and zooplankton: application to treatment of ballast water. Mar Pollut Bull 56:1201-1208

Hoyer O, Clasen J (2002) The application of new technologies in the water treatment process of a modern waterworks. Water Sci Technol 2:63-69

Hu H, Hong Y (2008) Algal-bloom control by allelopathy of aquatic macrophytes-a review. Front Environ Sci Eng China 2:421-438

Huang Y, Bai Y, Wang Y, Kong H (2013) Allelopathic effects of the extracts from an invasive species Solidago canadensis L. on Microcystis aeruginosa. Lett Appl Microbiol 57:451-458

Hudnell HK, Jones C, Labisi B, Lucero V, Hill DR, Eilers J (2010) Freshwater harmful algal bloom (FHAB) suppression with solar powered circulation (SPC). Harmful Algae 9:208-217

Iredale RS, McDonald AT, Adams DG (2012) A series of experiments aimed at clarifying the mode of action of barley straw in cyanobacterial growth control. Water Res 46:6095-6103
Jančula D, Maršálek B (2011) Critical review of actually available chemical compounds for prevention and management of cyanobacterial blooms. Chemosphere 85: 1415-1422

Jančula D, Suchomelová J, Gregor J, Smutná M, Maršálek B, Táborská E (2007) Effects of aqueous extracts from five species of the family Papaveraceae on selected aquatic organisms. Environ Toxicol 22:480-486

Jančula D, Matthijs HCP, Visser PM, Maršálek B (2016) Existing and emerging cyanocidal compounds: new perspectives for cyanobacterial bloom mitigation. Aquat Ecol

Janse JH, De Senerpont Domis LN, Scheffer M, Lijklema L, van Liere L, Klinge M, Mooij WM (2008) Critical phosphorus loading of different types of shallow lakes and the consequences for management estimated with the ecosystem model PCLake. Limnologica 38:203-219

Joo S, Foldenyi R (2012) Removal of dissolved organic matter (DOM) from water with activated carbon and effective microorganisms. Water Sci Technol 12:65-71

Joyce E, Phull SS, Lorimer JP, Mason TJ (2003) The development and evaluation of ultrasound for the treatment of bacterial suspensions. A study of frequency, power and sonication time on cultured Bacillus species. Ultrason Sonochem 10:315-318

Joyce EM, Wu X, Mason TJ (2010) Effect of ultrasonic frequency and power on algae suspensions. J Environ Sci Heal A 45:863-866

Jóźwiakowski K, Czernaś K, Szczurowska A (2009) Preliminary results of studies on the purification of water in a pond using the SCD Probiotics technology. Ecohydrol Hydrobiol 9:307-312

Kardinaal E, De Haan M, Ruiter H (2008) Maatregelen ter voorkoming blauwalgen werken onvoldoende $\mathrm{H} 2 \mathrm{O}(7)$ :4-7 (In Dutch)

Kelly LA, Smith S (1996) The nutrient budget of a small eutrophic loch and the effectiveness of straw bales in controlling algal blooms. Freshw Biol 36:411-418

Klapper H (1991) Control of Eutrophication in Inland Waters (Ellis Horwood Series in Water and Wastewater Technology). Ellis Horwood Ltd

Kotopoulis S, Schommartz A, Postema M (2009) Sonic cracking of blue-green algae. Appl Acoust 70:1306-1312

Lee TJ, Nakano K, Matsumara M (2001) Ultrasonic irradiation for blue-green algae bloom control. Environ Technol 22:383-390

Lee TJ, Nakano K, Matsumara M (2002) A novel strategy for cyanobacterial bloom control by ultrasonic irradiation. Water Sci Technol 46:207-215

Leeper DA, Porter KG (1995) Toxicity of the mixotrophic chrysophyte Poterio-ochromonas malhamensis to the cladoceran Daphnia ambigua. Arch Hydrobiol 134: 207-222

Lepistö L, Rapala J, Lyra C, Berg KA, Erkomaa K, Issakainen J (2005) Occurrence and toxicity of cyanobacterial blooms dominated by Anabaena lemmermannii P. Richter and Aphanizomenon spp. in boreal lakes in 2003. Algol Stud 117:315-328

Li L, Pan G (2013) A universal method for flocculating harmful algal blooms in marine and fresh waters using modified sand. Environ Sci Technol 47:4555-4562 
Li H, Pan G (2015) Simultaneous removal of harmful algal blooms and microcystins using microorganism- and chitosan-modified local soil. Environ Sci Technol 49:6249-6256

Lürling M, Beekman W (2006) Palmelloids formation in Chlamydomonas reinhardtii: defence against rotifer predators? Ann Limnol Int J Lim 42:65-72

Lürling M, Beekman W (2010) Anti-cyanobacterial activity of Moringa oleifera seeds. J Appl Phycol 22:503-510

Lürling M, Tolman Y (2014a) Beating the blues: Is there any music in fighting cyanobacteria with ultrasound? Water Res 66:361-373

Lürling M, Tolman Y (2014b) Effects of commercially available ultrasound on the zooplankton grazer Daphnia and consequent water greening. Water 6:3247-3263

Lürling M, van Oosterhout F (2013) Controlling eutrophication by combined bloom precipitation and sediment phosphorus inactivation. Water Res 47:6527-6537

Lürling M, van Oosterhout F (2014) Effect of selected plant extracts and D- and L-lysine on the cyanobacterium $\mathrm{Mi}$ crocystis aeruginosa. Water 6:1807-1825

Lürling M, Tolman Y, Euwe M (2009) Mitigating cyanobacterial blooms: how effective are 'effective microorganisms'? Lakes Reserv Res Manag 14:353-363

Lürling M, Tolman Y, van Oosterhout F (2010) Cyanobacteria blooms cannot be controlled by Effective Microorganisms $\left(\mathrm{EM}^{\circledR}\right)$ from mud- or Bokashi-balls. Hydrobiologia 646:133-143

Lürling M, Meng D, Faassen EJ (2014) Effects of hydrogen peroxide and ultrasound on biomass reduction and toxin release in the cyanobacterium, Microcystis aeruginosa. Toxins 6:3260-3280

Mackay EB, Maberly SC, Pan G, Reitzel K, Bruere A, Corker N, Douglas G, Egemose S, Hamilton D, Hatton-Ellis T, Huser B, Li W, Meis S, Moss B, Lürling M, Phillips G, Yasseri S, Spears BM (2014) Geoengineering in lakes: welcome attraction or fatal distraction? Inland Waters 4:349-356

Martin D, Ridge I (1999) The relative sensitivity of algae to decomposing barley straw. J Appl Phycol 11:285-291

Mason TJ (2007) Developments in ultrasound-Non-medical. Prog Biophys Mol Biol 93:166-175

Matthijs HCP, Visser PM, Reeze B, Meeuse J, Slot PC, Wijn G, Talens R, Huisman J (2012) Selective suppression of harmful cyanobacteria in an entire lake with hydrogen peroxide. Water Res 46:1460-1472

Merel S, Walker D, Chicana R, Snyder S, Baurès E, Thomas O (2013) State of knowledge and concerns on cyanobacterial blooms and cyanotoxins. Environ Int 59:303-327

Mohamed ZA, Shehri AM (2010) Differential responses of epiphytic and planktonic toxic cyanobacteria to allelopathic substances of the submerged macrophyte Stratiotes aloides. Int Rev Hydrobiol 95:224-234

Mulderij G, Mooij WM, Smolders AJP, van Donk E (2005) Inhibition of phytoplankton by allelopathic substances from Stratiotes aloides. Aquat Bot 82:284-296

Mulderij G, Mau B, van Donk E, Gross EM (2007) Allelopathic activity of Stratiotes aloides on phytoplankton - towards identification of allelopathic substances. Hydrobiologia 584:89-100

Neppiras EA (1980) Phys Rep (Rev Sect Phys Lett) 61:159-251
Newman J, Barrett P (1993) Control of Microcystis aeruginosa by decomposing barley straw. J Aquat Plant Manage 31:203-206

Noyma N, de Magalhães L, Lima Furtado L, Mucci M, van Oosterhout F, Huszar VLM, Manzi Marinho M, Lürling M (2015) Controlling cyanobacterial blooms through effective flocculation and sedimentation with combined use of flocculants and phosphorus adsorbing natural soil and modified clay. Water Res. doi:10.1016/j.watres.2015.11. 057

O’Neil JM, Davis TW, Burford MA, Gobler CJ (2012) The rise of harmful cyanobacteria blooms: the potential roles of eutrophication and climate change. Harmful Algae 14: 313-334

Oberholster PJ, Botha AM, Cloete TE (2006) Toxic cyanobacterial blooms in a shallow, artificially mixed urban lake in Colorado, USA. Lakes Reserv Res Manag 11:111-123

Ou D, Song L, Gan N, Chen W (2005) Effects of microcystins on and toxin degradation by Poterioochromonas sp. Environ Toxicol 20:373-380

Padisák J (2014) Transparency of garden pond failed be controlled by effective microorganisms. In: Book of Abstract 8th Shallow Lakes Conference, p 63

Paerl H (2008) Nutrient and other environmental controls of harmful cyanobacterial blooms along the freshwatermarine continuum. Adv Exp Med Biol 619:217-237

Paerl HW, Huisman J (2008) Blooms like it hot. Science 320:57-58

Paerl HW, Otten TG (2013) Blooms bite the hand that feeds them. Science 342:433-434

Paerl HW, Fulton RS, Moisander PH, Dyble J (2001) Harmful freshwater algal blooms, with an emphasis on cyanobacteria. TheScientificWorld 1:76-113

Paerl HW, Hall NS, Calandrino ES (2011) Controlling harmful cyanobacterial blooms in a world experiencing anthropogenic and climatic-induced change. Sci Tot Environ 409:1739-1745

Pakdel FM, Sim L, Beardall J, Davis J (2013) Allelopathic inhibition of microalgae by the freshwater stonewort, Chara australis, and a submerged angiosperm, Potamogeton crispus. Aquat Bot 110:24-30

Pan G, Zhang M-M, Chen H, Zou H, Yan H (2006a) Removal of cyanobacterial blooms in Taihu Lake using local soils. I. Equilibrium and kinetic screening on the flocculation of Microcystis aeruginosa using commercially available clays and minerals. Environ Poll 141:195-200

Pan G, Zou H, Chen H, Yuan X (2006b) Removal of harmful cyanobacterial blooms in Taihu Lake using local soils III. Factors affecting the removal efficiency and an in situ field experiment using chitosan-modified local soils. Environ Poll 141:206-212

Pan G, Yang B, Wang D, Chen H, Tian B-H, Zhang M-L, Yuan X-Z, Chen J (2011a) In-lake algal bloom removal and submerged vegetation restoration using modified local soils. Ecol Eng 37:302-308

Pan G, Chen J, Anderson DM (2011b) Modified local sands for the mitigation of harmful algal blooms. Harmful Algae 10:381-387

Park MH, Han MS, Ahn CY, Kim HS, Yoon BD, Oh HM (2006) Growth inhibition of bloom-forming cyanobacterium 
Microcystis aeruginosa by rice straw extract. Lett Appl Microbiol 43:307-312

Park MH, Chung IM, Ahmad A, Kim BH, Hwang SJ (2009) Growth inhibition of unicellular and colonial Microcystis strains (Cyanophyceae) by compounds isolated from rice (Oryza sativa) hulls. Aquat Bot 90:309-314

Pastorok RA, Ginn TC, Lorenzen MW (1980) Review of aeration/circulation for lake management in restoration of lakes and inland waters. In: Proceedings of international conference, Portland, Main, pp 124-133

Phelan RR, Downing TG (2011) A growth advantage for microcystin production by Microcystis PCC7806 under high light. J Phycol 47:1241-1246

Phull SS, Newman AP, Lorimer JP, Pollet B, Mason TJ (1997) The development and evaluation of ultrasound in the biocidal treatment of water. Ultrason Sonochem 4:157-164

Pillinger JM, Cooper JA, Ridge I (1994) Role of phenolic compounds in the antialgal activity of barley straw. J Chem Ecol 20:1557-1569

Purcell D, Parsons SA, Jefferson B, Holden S, Campbell A, Wallen A, Chipps M, Holden B, Ellingham A (2013) Experiences of algal bloom control using green solutions barley straw and ultrasound, an industry perspective. Water Environ J 27:148-156

Rajabi H, Filizadeh Y, Soltani M, Fotokian MH (2010) The use of barley straw for controlling cyanobacteria under field application. J Fish Aquat Sci 5:394-401

Rajasekhar P, Fan L, Nguyen T, Roddick FA (2012a) A review of the use of sonication to control cyanobacterial blooms. Water Res 46:4319-4329

Rajasekhar P, Fan L, Nguyen T, Roddick FA (2012b) Impact of sonication at $20 \mathrm{kHz}$ on Microcystis aeruginosa, Anabaena circinalis and Chlorella sp. Water Res 46:1473-1481

Ridge I, Pillinger J (1996) Towards understanding the nature of algal inhibitors from barley straw. Hydrobiologia 340:301-305

Rijkswaterstaat (2007) Advies Beheer-en bestrijdingsmaatregelen Blauwalg (in Dutch)

Rodriguez-Molares A, Dickson S, Hobson P, Howard C, Zander A, Burch M (2014) Quantification of the ultrasound induced sedimentation of Microcystis aeruginosa. Ultrason Sonochem 21:1299-1304

Roozen FCJM, Lürling M, Vlek H, Van Der Pouw Kraan EAJ, Ibelings BW, Scheffer M (2007) Resuspension of algal cells by benthivorous fish boosts phytoplankton biomass and alters community structure in shallow lakes. Freshwater Biol 52:977-987

Saunders RW, Leeper DA, King CA, Porter KG (1994) Grazing by rotifers and crustacean zooplankton on nanoplanktonic protists. Hydrobiologia 288:167-181

Scheffer M, Hosper SH, Meijer ML, Moss B, Jeppesen E (1993) Alternative equilibria in shallow lakes. Trends Ecol Evol 8:275-279

Scheffer M, Rinaldi S, Gragnani A, Mur LR, Van Nes EH (1997) On the dominance of filamentous cyanobacteria in shallow, turbid lakes. Ecology 78:272-282

Shanab SMM, Shalaby EA, Lightfoot DA, El-Shemy HA (2010) Allelopathic effects of water hyacinth (Eichhornia crassipes). PLoS ONE 5(10):e13200

Shao J, Li R, Lepo JE, Gu J-D (2013) Potential for control of harmful cyanobacterial blooms using biologically derived substances: problems and prospects. J Environ Manage 125:149-155

Shimada K, Kitamura N, Yoshida Y, Matsushima H, Asada Y (2010) Effects of water soluble extract from the dead leaves of deciduous trees on the growth control of toxic cyanobacteria like Microcystis aeruginosa. WIT Trans Ecol Environ 135:71-82

Smith VH, Tilman GD, Nekola JC (1999) Eutrophication: impacts of excess nutrient inputs on freshwater, marine, and terrestrial ecosystems. Environ Poll 100:179-196

Sommer U, Gliwicz ZM, Lampert W, Duncan A (1986) The PEG-Model of seasonal succession of planktonic events in fresh waters. Arch Hydrobiol 106:433-471

Sommer U, Adrian R, De Senerpont Domis LN, Elser JJ, Gaedke U, Ibelings BW, Jeppesen E, Lürling M, Molinero JC, Mooij WM, Van Donk E, Winder M (2012) Beyond the PEG model: mechanisms driving plankton succession. Annu Rev Ecol Evol S 43:429-448

Søndergaard M, Jensen JP, Jeppesen E (1999) Internal phosphorus loading in shallow Danish lakes. Hydrobiologia 408:145-152

Spencer D, Lembi C (2007) Evaluation of barley straw as an alternative algal control method in northern California rice fields. J Aquat Plant Manag 45:84-90

Steffensen DA (2008) Economic cost of cyanobacterial blooms. Adv Exp Med Biol 619:855-865

Takeda F, Nakano K, Aikawa Y, Nishimura O, Shimada Y, Fukuro S, Tanaka H, Hayashi N, Inamori Y (2011) Allelopathic potential against Microcystis aeruginosa by emergent macrophytes on floating beds. J Water Environ Technol 9:371-380

Tang JW, Wu QY, Hao HW, Chen Y, Wu M (2004) Effect of 1.7 MHz ultrasound on a gas-vacuolate cyanobacterium and a gas-vacuole negative cyanobacterium. Colloid Surface B 36:115-121

Terlizzi DE, Ferrier MD, Armbrester EA, Anlauf KA (2002) Inhibition of dinoflagellate growth by extracts of barley straw (Hordeum vulgare). J Appl Phycol 14:275-280

Thomas BJ, Mclntosh D, Taylor SR, Francko DA, Ownby J (1989) Effect of low-dose ultrasonic treatment on growth rates and biomass yield of Anabaena flos-aquae and Selenastrum capricornutum. Biotechnol Tech 3:389-392

URL1 (2014) http://www.multikraft.com/en/home-and-garden/ pond-pool.html. Accessed 7 Dec 2014

URL2 (2014) http://www.teraganix.com/Effective-Microorgani sms-and-Water-Clarity-s/53.htm. Accessed 7 Dec 2014

URL3 (2014) http://www.recycleworks.co.uk/em-bokashi-mudball-pr-16301.html. Accessed 7 Dec 2014

URL4 (2014) http://www.emvereniging.nl/?cat=33. Accessed 7 Dec 2014

URL5 (2014) http://www.emsustains.co.uk/water.htm. Accessed 7 Dec 2014

URL6 (2013) http://www.emearth.com/newpdfdocuments/poolsnew.pdf. Accessed 29 Oct 2013

URL7 (2014) http://www.lgsonic.com/lg-sonic-vs-cavitation/. Accessed 2 Aug 2014

URL8 (2014) http://www.flexidal.com/nl/uitlegoverdeprodukten vanflexidal_algen.asp?paginaid=5\&rubriek=algen. Accessed 2 Aug 2014

URL9 (2014) http://www.lgsonic.com/lg-sonic-vs-cavitation/. Accessed 2 Aug 2014 
URL10 (2014) http://flexidal.be/nl/produktenvanflexidal_algen. asp?rubriek=algen \&fotoid=8. Accessed 2 Aug 2014

URL11 (2015) http://www.dommel.nl/algemeen/actueel/maatre gelen/blauwalgen-en-botulisme/onderzoek-blauwalgproble matiek.html. Accessed 4 Sept 2015

URL12 (2015) http://www.dommel.nl/algemeen/actueel/maatre gelen/blauwalgen-en-botulisme/proef-verbetering-waterkwa liteit-stadsvijver-kaukasuslaan-tilburg.html. Accessed 4 Sept 2015

URL13 (2015) http://www.mhwaterzaken.nl/oxatur/oxaturin troducti.html. Accessed 4 Sept 2015

URL14 (2015) http://www.blauwalgen.eu/English/Onderzoek. htm. Accessed 4 Sept 2015

Van Donk E, Cerbin S, Wilken S, Helmsing NR, Ptacnik R, Verschoor AM (2009) The effect of a mixotrophic chrysophyte on toxic and colony-forming cyanobacteria. Freshw Biol 54:1843-1855

Van Egeraat AWSM (1998) EM1 and the Growth of Microorganisms. Micro-organisms in EM1. Wageningen University report

Van Vliet PCJ, Bloem J, de Goede RGM (2006) Microbial diversity, nitrogen loss and grass production after addition of Effective Micro-organisms ${ }^{\circledR}$ (EM) to slurry manure. Appl Soil Ecol 32:188-198

Visser PM, Ibelings BW, Bormans M, Huisman J (2016) Artificial mixing to control cyanobacterial blooms: a review. Aquat Ecol. doi:10.1007/s10452-015-9537-0

Vollenweider RA (1976) Advances in defining critical loading levels for phosphorus in lake eutrophication. Memorie dell'Instituto Italiano di Idrobiologia 33:53-83

Waajen G, Van Oosterhout F, Douglas G, Lürling M (2015) Management of eutrophication in Lake De Kuil (The Netherlands) using combined flocculant-lanthanum modified bentonite treatment. Water Res. doi:10.1016/j. watres.2015.11.034

Walsby AE (1994) Gas vesicles. Microbiol Rev 58:94-144

Walsby AE, Hayes PK (1989) Gas vesicle proteins. Biochem J 264:313-322

Wang W, Liu Y, Yang Z (2010) Combined effects of nitrogen content in media and Ochromonas sp. grazing on colony formation of cultured Microcystis aeruginosa. J Limnol 69:193-198

Welch IM, Barrett PRF, Gibson MT, Ridge I (1990) Barley straw as an inhibitor of algal growth I: studies in the Chesterfield Canal. J Appl Phycol 2:231-239

Wu J, Wu M (2006) Feasibility study of effect of ultrasound on water chestnuts. Ultrasound Med Biol 32:595-601

Wu C, Chang X, Dong H, Li D, Liu J (2008) Allelopathic inhibitory effect of Myriophyllum aquaticum (Vell.) Verdc. on Microcystis aeruginosa and its physiological mechanism. Acta Ecol Sin 28:595-2603

Wu X, Joyce EM, Mason TJ (2011) The effects of ultrasound on cyanobacteria. Harmful Algae 10:738-743

Wu X, Joyce EM, Mason TJ (2012) Evaluation of the mechanisms of the effect of ultrasound on Microcystis aeruginosa at different ultrasonic frequencies. Water Res 46:28512858

Wu X, Wu H, Chen J, Ye J (2013) Effects of allelochemical extracted from water lettuce (Pistia stratiotes Linn.) on the growth, microcystin production and release of Microcystis aeruginosa. Environ Sci Pollut Res 20:8192-8201
Xiao X, Huang H, Ge Z, Rounge TB, Shi J, Xu X, Li R, Chen Y (2014) A pair of chiral flavonolignans as novel anticyanobacterial allelochemicals derived from barley straw (Hordeum vulgare): characterization and comparison of their anti-cyanobacterial activities. Environ Microbiol 16:1238-1251

Yan R, Ji H, Wu Y, Kerr PG, Fang Y, Yang L (2012) An investigation into the kinetics and mechanism of the removal of cyanobacteria by extract of Ephedra equisetina root. PLoS One 7(8):e42285

Yang Z, Kong F (2012) Formation of large colonies: a defense mechanism of Microcystis aeruginosa under continuous grazing pressure by flagellate Ochromonas sp. J Limnol 71:61-66

Yang SQ, Liu PW (2010) Strategy of water pollution prevention in Taihu Lake and its effects analysis. J Gt Lakes Res 36:150-158

Yang J-D, Hu L-B, Zhou W, Yin Y-F, Chen J, Shi Z-Q (2009a) Lysis of Microcystis aeruginosa with extracts from Chinese medicinal herbs. Int J Mol Sci 10:4157-4167

Yang Z, Kong F, Yang Z, Zhang M, Yu Y, Qian S (2009b) Benefits and costs of the grazer-induced colony formation in Microcystis aeruginosa. Ann Limnol Int J Lim 45:203-208

Yang Z, Kong FX, Zhang M, Yang Z, Yu Y, Qian SQ (2009c) Effect of filtered cultures of flagellate Ochromonas sp. on colony formation in Microcystis aeruginosa. Int Rev Hydrobiol 94:143-152

Zakaria Z, Gairola S, Shariff NM (2010) Effective Microorganisms (EM) technology for water quality restoration and potential for sustainable water resources and management. In: Proceedings international congress on environmental modelling and software, S0. Open session, S.0.04 http:// www.iemss.org/iemss2010/proceedings.html

Zhang XM, Watanabe MM (2001) Grazing and growth of the mixotrophic chrysomonad Poterioochromonas malhamensis (Chrysophyceae) feeding on algae. J Phycol 37:738-743

Zhang XM, Watanabe MM, Inouye I (1996) Light and electron microscopy of grazing by Poterioochromonas malhamensis (Chrysophyceae) on a range of phytoplankton taxa. J Phycol 32:37-46

Zhang G, Zhang P, Wang B, Liu H (2006) Ultrasonic frequency effects on the removal of Microcystis aeruginosa. Ultrason Sonochem 13:446-450

Zhang X, Hu HY, Men YJ, Yang J, Christoffersen K (2009a) Feeding characteristics of a golden alga (Poterioochromonas sp.) grazing on toxic cyanobacterium $\mathrm{Mi}$ crocystis aeruginosa. Water Res 43:2953-2960

Zhang X, Warming TP, Hu HY, Christoffersen K (2009b) Life history responses of Daphnia magna feeding on toxic $M i$ crocystis aeruginosa alone and mixed with a mixotrophic Poterioochromonas species. Water Res 43:5053-5062

Zhang C, Yi Y-L, Hao K, Liu G-L, Wang G-X (2013) Algicidal activity of Salvia miltiorrhiza Bung on Microcystis aeruginosa-towards identification of algicidal substance and determination of inhibition mechanism. Chemosphere 93:997-1004

Zhou LR, Hou LL, Hu YY, Song JG, Chen WQ (2010) Effects of the plant extract of wattle (Acacia mimosa) on the growth of Microcystic aeruginosa and the simulated mini fresh water ecosystem. J Environ Biol 31:1023-1030 
Zhou L, Bi Y, Jiang L, Wang Z, Chen W (2012) Effect of black wattle (Acacia mearnsii) extract on blue-green algal bloom control and plankton structure optimization: a field mesocosm experiment. Water Environ Res 84:2133-2142

Zilliges Y, Kehr J-C, Meissner S, Ishida K, Mikkat S, Hagemann M, Kaplan A, Börner T, Dittmann E (2011) The cyanobacterial hepatotoxin microcystin binds to proteins and increases the fitness of Microcystis under oxidative stress conditions. PLoS One 6(3):e17615

Zou H, Pan G, Chen H, Yuan X (2006) Removal of cyanobacterial blooms in Taihu Lake using local soils II. Effective removal of Microcystis aeruginosa using local soils and sediments modified by chitosan. Environ Poll 141:201-205 